\title{
ANATOMY, MORPHOLOGY, AND CLADISTIC ANALYSIS OF MONSONIA L. (GERANIACEAE)
}

\author{
by \\ JUAN JOSÉ ALDASORO ', CARMEN NAVARRO 2 , PABLO VARGAS ' \& CARLOS AEDO ' \\ ' Real Jardín Botánico, CSIC. Plaza de Murillo, 2. E-28014 Madrid \\ ${ }^{2}$ Departamento de Biología Vegetal II, Facultad de Farmacia, Universidad Complutense. E-28040 Madrid
}

\begin{abstract}
Resumen
Aldasoro, J.J., C. Navarro, P. Vargas \& C. Aedo (2001). Anatomía, morfología y análisis cladístico de Monsonia L. (Geraniaceae). Anales Jard. Bot. Madrid 59(1): 75-100 (en inglés).

Se exploran mediante un análisis cladístico las relaciones filogenéticas entre las 25 especies incluidas en el género Monsonia. Tras una detallada revisión se seleccionan 20 caracteres morfológicos y anatómicos, entre ellos algunos previamente no descritos sobre los nectarios, el androceo y los mericarpos. El análisis filogenético produjo nueve árboles más parsimoniosos. El árbol de consenso estricto muestra dos clados principales: uno, formado por las nueve especies de Monsonia sect. Monsonia, caracterizadas por las aristas plumosas y las tres de Sarcocaulon que se usaron como grupo externo; y el segundo, formado por las 16 especies de Monsonia sect. Olopetalum, que comparten el tipo de separación del mericarpo, la consistencia de la columela y las paredes gruesas en el mericarpo. Como consecuencia surgen nuevas dudas sobre la monofilia de Monsonia. Sin embargo, nuestros datos apoyan la clasificación subgenérica actual de Monsonia si se incluyen $M$. longipes y $M$. speciosa en la sect. Olopetalum. Numerosos caracteres del mericarpo están relacionados con el tipo de zoocoria, lo cual parece derivado en Monsonia al igual que en otras geraniáceas.
\end{abstract}

Palabras clave: anatomía, morfología, análisis cladístico, Monsonia, Geraniaceae.

\begin{abstract}
Aldasoro, J.J.. C. Navarro, P. Vargas \& C. Aedo (2001). Anatomy, Morphology, and Cladistic Analysis of Monsonia L. (Geraniaceae). Anales Jard. Bot. Madrid 59(1): 75-100.

Phylogenetic relationships among the 25 species of the old-world genus Monsonia are explored by means of a cladistic analysis. After a detailed revision, 20 morphological and anatomical characters were selected, including some new ones from nectaries, androecium, and mericarps. Phylogenetic analysis yielded 9 most parsimonious trees. The strict consensus tree showed two major clades: one is formed by the 9 species of Monsonia sect. Monsonia, characterised by plumose awns, plus Sarcocaulon; and a second with the 16 species of Monsonia sect. Olopetalum which share the type of mericarp detaching, consistency of columella and the thick mericarp walls. Consequently. some doubts about the monophyly of Monsonia exists. However, the current infrageneric classification of Monsonia is supported after transferring $M$. longipes and $M$. speciosa to sect. Olopetalum. Several characters of the mericarp are related to zoochory, which seems to be a derived syndrome in Monsonia, as in the other Geraniaceae.
\end{abstract}

Key words: anatomy, morphology, cladistics, Monsonia, Geraniaceae. 


\section{INTRODUCTION}

Geraniaceae comprises five genera with rostrate schizocarp: Erodium L'Hér., Geranium L., Monsonia L., Sarcocaulon (DC.) Sweet, and Pelargonium L'Hér. (HuTCHINSON, 1969). Two tribes are recognised: Geranieae with primarily actinomorphic flowers (Erodium, Geranium, Monsonia, and Sarcocaulon), and Pelargonieae with zygomorphic flowers (Pelargonium). The family is distributed worldwide and well represented in Southern Africa with four native genera: Geranium. Monsonia, Pelargonium and Sarcocaulon. Monsonia consists of 25 species distributed in Africa, Madagascar, and SW Asia, 18 of them being endemic to Southern Africa.

De Candolle (1824) divided Monsonia into three sections: sect. Sarcocaulon, sect. Olopetalum, and sect. Odontopetalum. SWEET (1826) raised Monsonia sect. Sarcocaulon to generic rank, a taxonomic criterion adopted in the most recent monographs (KNUTH 1912; Venter 1979; Moffett 1979). BoIsSIER (1867) proposed an alternative classification with only two sections, sect. Plumosa, characterized by long, plumose mericarp awns, and sect. Barbata, defined by shorter but robust awns. KNUTH (1912) divided Monsonia into 7 sections, based on life form and leaf and corolla shape, which was criticised by several authors (VENTER 1979; YEO 1990). VENTER (1979) and VERHOEVEN \& VENTER (1986) reinstated and rearranged Boissier's classification, dividing Monsonia in two sections: Monsonia (= Plumosa), including plants with long plumose awns; and Olopetalum (= Barbata) including plants with shorter adhesive awns. These cited classifications are summarised in table 1.

ALBERS (1996) reconsidered the circumscription of Sarcocaulon and Monsonia, suggesting that there is no reason for maintaining both genera as separate. He based his decision on criteria such as similarity in flower structure, phenolic compounds, protein patterns and chromosome numbers. However, some of these data are still unpublished. DREYER \& al. (1997) and MoFFET (1997) criticised Albers' proposal on the grounds that the present knowledge of the genus is not sufficient and a molecular study is needed. Besides, these authors consider that macro-morphological differences between the two genera are clear and well-defined.

Apart from the two comprehensive monographs (KNUTH 1912; VENTER 1979), partial studies of Monsonia were carried out on pollen morphology (VERHOEVEN \& VENTER, 1986), embryology (NARAYANA \& ARORA, 1963), mericarp and seed arrangement (YEO, 1990), anatomy of nectaries (LINK, 1990) and phytogeography (VENTER, 1983). A grouping analysis based on morphological features was performed by VENTER (1990), supporting his sectional treatment of Monsonia. KERS (1968) and VENTER (1983) assessed the geographical distribution and habitats in Monsonia. The 25 species inhabit grasslands, savannas, and deserts in Africa and Southwest Asia. The highest diversity of the genus can be found in southern Africa with 21 of the 25 species, of which 9 are endemic to South Africa and 7 to Namibia.

Previous studies in Monsonia show a remarkable broad range of morphological variation (VENTER 1979). Species vary in life form, root type, leaf and stipule shape, inflorescence types, sepal and gynoecium indumentum, petal size, nectary types, anther size, stamen number, exine ornamentation, stigma size and shape, fruit features, cotyledon arrangement.

A phylogenetic study of Geraniaceae using $r b c \mathrm{~L}$ sequences was performed by PRICE \& PALMER (1993). They found Sarcocaulon to be sister to Monsonia, with Pelargonium sister to the other four genera of Geraniaceae. The relationship between Monsonia and Sarcocaulon is also supported by the loss of the rpl2 intron (PrICE \& al., 1990; DowNIE \& PALMER, 1992).

The specific objectives of this study on Monsonia were to: 1) re-evaluate morphological characters used in previous monographs; 2) search for new morphological and anatomical characters; and 3) analyse phylogenetic relationships among the species using parsimony. 


\section{MATERIAL AND METHODS}

This paper is based on herbarium specimens, studied in the following herbaria: $\mathrm{B}$, BM, COI, G, K, LE, MA, MO, MPU, P, W and WAG. Specimens used in anatomical studies are listed in Appendix 1. In this study we follow the taxonomic treatment proposed by VENTER $(1979,1983)$.

Dried flowers from herbarium specimens were soaked in warm water with $1 \% \mathrm{NaOH}$ or with 2-3 drops of liquid soap; after two hours they were transferred to water for one hour and then to $50 \%$ ethanol. Mericarps and flowers removed from herbarium specimens were rehydrated for light photography, hand-cut sections obtained, and tissues differentially stained. Sections were made with a SLEEMAINZ-MTC microtome, stained with Fasga mixture, which is made of Safranin and Alcyan green 2GX (Gurr Chemical Co.) (ToLIVIA \& TOLIVIA, 1987), and photographed by light microscopy. Flowers and mericarps were sectioned, glued on aluminium stubs,

\section{TABLE 1}

COMPARISON OF MAIN INFRAGENERIC TREATMENTS OF Monsonia. SECTION (OR INFRAGENERIC RANK) NAME ARE INDICATED IN EACH COLUMN. SPECIES OF DOUBFUL ASSIGNATION ARE INDICATED BY “?”; SPECIES NOT CONSIDERED ARE INDICATED BY ".-"

\begin{tabular}{|c|c|c|c|c|c|c|c|}
\hline Species & this study & $\begin{array}{l}\text { Verhoeven \& } \\
\text { Venter (1986) }\end{array}$ & $\begin{array}{l}\text { Venter } \\
(1979) \\
\end{array}$ & $\begin{array}{c}\text { Kers } \\
(1968)\end{array}$ & $\begin{array}{l}\text { Knuth } \\
\text { (1912) }\end{array}$ & \begin{tabular}{|c|} 
Boissier \\
$(1867)$
\end{tabular} & $\begin{array}{c}\text { De Candolle } \\
(1824)\end{array}$ \\
\hline M. brevirostrata & Olopetalum & Olopetalum & Barbata & - & Biflora & - & - \\
\hline$M$. angustifolia & Olopetalum & Olopetalum & Barbata & - & Biflora & - & - \\
\hline M. senegalensis & Olopetalum & Olopetalum & Barbata & Barbata & Ovata & Barbatae & - \\
\hline M. natalensis & Olopetalum & Olopetalum & Barbata & - & Genistiformis & - & \\
\hline M. grandifolia & Olopetalum & Olopetalum & Barbata & - & Ovata & - & - \\
\hline M. emarginata & Olopetalum & Olopetalum & Barbata & - & Ovata & - & Olopetalum \\
\hline M. galpinii & Olopetalum & Olopetalum & Barbata & - & Ovata & - & - \\
\hline M. praemorsa & Olopetalum & Olopetalum & Barbata & - & Genistiformis & - & \\
\hline M. burkeana & Olopetalum & Olopetalum & Barbata & - & Genistiformis & - & Olopetalum \\
\hline M. glauca & Olopetalum & Olopetalum & Barbata & - & Ovata & - & - \\
\hline M. lanuginosa & Olopetalum & Olopetalum & Barbata & - & Genistiformis & - & - \\
\hline M. attenuata & Olopetalum & Olopetalum & Barbata & $=$ & Genistiformis & - & - \\
\hline M. tranvaalensis & Olopetalum & Olopetalum & Barbata & - & Genistiformis & - & - \\
\hline M. longipes & Olopetalum & Monsonia & Barbata & $?$ & Plumosa & - & - \\
\hline M. ignea & Olopetalum & Olopetalum & Barbata & $?$ & Plumosa & - & - \\
\hline M. speciosa & Olopetalum & Monsonia & Barbata & Plumosa & Odontopetalum & - & Odontopetalum \\
\hline M. drudeana & Monsonia & Monsonia & Plumosa & $?$ & Rotundatae & - & - \\
\hline M. deserticola & Monsonia & Monsonia & Plumosa & Plumosa & Rotundatae & - & - \\
\hline M. nivea & Monsonia & Monsonia & Plumosa & Plumosa & Plumosa & Plumosa & - \\
\hline M. heliotropioides & Monsonia & Monsonia & Plumosa & Plumosa & Plumosa & Plumosa & - \\
\hline M. umbellata & Monsonia & Monsonia & Plumosa & Plumosa & Umbellata & - & - \\
\hline M. luederitziana & Monsonia & Monsonia & Plumosa & Plumosa & Umbellata & - & - \\
\hline M. parvifolia & Monsonia & Monsonia & Plumosa & Plumosa & Umbellata & - & - \\
\hline M. trilobata & Monsonia & Monsonia & Plumosa & Barbata & - & - & - \\
\hline M. ignorata & Monsonia & Monsonia & Plumosa & Plumosa & - & $=$ & - \\
\hline
\end{tabular}


TABLE 2

THE 20 MORPHOLOGICAL CHARACTERS USED IN THE CLADISTIC ANALYSIS OF MONSONIA

\begin{tabular}{|c|c|}
\hline $\begin{array}{l}\text { Vegetative } \\
\text { structures }\end{array}$ & $\begin{array}{l}\text { States of characters } \\
\text { 1. Plant perennial }(0) \text {; annual (1). } \\
\text { 2. Plant not succulent }(0) \text {; plant succulent }(1) \text {. } \\
\text { 3. Stems not covered by bark }(0) \text {; stems covered with waxy bark (1). }\end{array}$ \\
\hline $\begin{array}{l}\text { Spines } \\
\text { and leaves }\end{array}$ & $\begin{array}{l}\text { 4. Spines absent ( } 0) \text {; spines present (1). } \\
\text { 5. Leaf veins palmate or subpalmate ( } 0) \text {; leaf veins pinnate or subpinnate (1). }\end{array}$ \\
\hline Stipules & $\begin{array}{l}\text { 6. Stipules plane, generally lanceolate }(0) \text {; stipules subulate or acicular (1). } \\
\text { 7. Stipules without a tuft of hairs on the top }(0) \text {; stipules with a tuft of hairs on the } \\
\text { top (1). }\end{array}$ \\
\hline Inflorescence & 8. Inflorescence cymose ( 0 ); inflorescence pseudoumbellate (1); solitary flowers (2). \\
\hline Flower & $\begin{array}{l}\text { 9. Sepals not enlarged or if enlarged not forming closed pouches }(0) \text {; sepals enlarged, } \\
\text { and the floral disc expanded forming a closed cavity to keep nectar }(1) \text {. } \\
\text { 10. Nectaries axillar, situated between the base of antisepal filament and the sepal, }(0) \text {; } \\
\text { nectaries staminal, forming a more or less conspicuous protuberance at the base of } \\
\text { staminal filament, with no tube inside (1); nectaries staminal, forming a more or } \\
\text { less conspicuous protuberance with a pocket inside, and continued by a conic tube } \\
\text { in the receptacle (2). } \\
\text { 11. Anthers longer than } 1.7 \mathrm{~mm}(0) \text {; anthers very small, shorter than } 1 \mathrm{~mm}(1) \text {. } \\
\text { 12. Pollen without supratectal processes }(0) \text {; with supratectal processes (1). }\end{array}$ \\
\hline Fruit & $\begin{array}{l}\text { 13. Fruit detaching upwards }(0) \text {; downwards }(1) \text {. } \\
\text { 14. Columella consistency, weak }(0) \text {; stout (1). } \\
\text { 15. Awn not plumose }(0) \text {; awn more or less plumose }(1) \text {. } \\
\text { 16. Mericarp gradually tapered to the awn }(0) \text {; slightly tapered, or abruptely cutted by } \\
\text { pits or ridges perpendicular to awn }(1) \text {. } \\
\text { 17. Mericarp with only one type of bristles }(0) \text {; with two types of bristles, few long and } \\
\text { many short (1). } \\
\text { 18. Mericarp bristles without pockets }(0) \text {; with pockets }(1) \text {. } \\
\text { 19. Mericarp wall narrower than } 20 \mathrm{~mm}(0) \text {; wider than } 30 \mathrm{~mm}(1) \text {. }\end{array}$ \\
\hline Seed & $\begin{array}{l}\text { 20. Seed with plane cotyledons }(0) \text {; moderately folded cotyledons, non conduplicate } \\
\text { (1), clearly folded, conduplicate cotyledons (2). }\end{array}$ \\
\hline
\end{tabular}

coated with $40-50 \mathrm{~nm}$ gold, and examined in a JEOL-TSM T330A scanning electron microscope (SEM) at $20 \mathrm{kV}$.

Cladistic analyses species were conducted using Fitch parsimony (as implemented in PAUP 3.0; SWOFFORD, 1993) with unordered and equal weighting all characters. Heuristic searches were replicated 100 times using random taxon entries and ACCTRAN optimization. The 25 species belonging to the two sections of Monsonia ( 9 in sect. Monsonia and 16 in sect. Olopetalum) were included as the ingroup. Pelargonium peltatum, was chosen as the outgroup based on previous chloroplast sequence analyses (PRICE \& PALMER 1993) in which this genus is basal to the other genera of Geraniaceae: Sarcocaulon, Erodium, Geranium, and Monsonia. Other species of Pelargonium were also studied in order to test if some states of a character were present in all of them. To test the monophyly of Monsonia, three species of Sarcocaulon (S. crassifolium, $S$. marlothii and S. mossamedense) were also included in the analysis. MacClade version 3.04 was used to reconstruct character evolution (MADDISON \& MADDISON, 1992). Reliability of clades was assessed by bootstrapping (using 100 replicates addition) (FELSENSTEIN, 1985). A total of 20 morphological and anatomical characters (tables 2,3 ) were used 
in the cladistic analysis, two of them being quantitative (anther length and mericarp wall width). Some other characters were studied but finally excluded from the analysis because of either high instance of polymorphism or we did not observe discontinuities to define character states. The excluded characters are: presence of tuberose roots, subacaule or acaule habit, presence and length of sepal mucro, petal size, presence or absence of stalked glandular hairs on the ovary, shape of bristle tip and pits on the mericarp body, reticulate ornamentation and papillae types on the mericarp surface, and presence and distribution of glandular hairs.

\section{RESULTS}

\section{Morphological characters}

A matrix of characters with potential phylogenetic information is shown in tables 2 and 3 , and discussed below.

Life form.-Most species of Monsonia are perennials, except for $M$. senegalensis, $M$. brevirostrata and $M$. angustifolia (tables 2 and 3 , character 1 ). The same is true for Pelargonium. Three main types of roots are recognized in Monsonia but not used in the analysis: (1) vertical napiform roots, with finer lateral rootlets (annuals); (2) vertical branched roots, sometimes with tubers

TABLE 3

DATA MATRIX USED IN CLADISTIC ANALYSIS OF MONSONIA. INAPPLICABLE OR MISSING DATA ARE CODED AS "?"

\begin{tabular}{|c|c|c|c|c|c|c|c|c|c|c|c|c|c|c|c|c|c|c|c|c|}
\hline & 1 & 2 & 3 & 2 & 5 & 6 & 7 & 8 & 9 & & & & & & & & & & & \\
\hline gonium & 0 & 0 & 0 & 0 & 0 & 0 & 0 & 1 & : & ${ }^{\circ}$ & 0 & 0 & 0 & 1 & 0 & 0 & 0 & 0 & 0 & 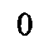 \\
\hline Sarcocaulon crassi & 0 & 1 & 1 & 1 & 0 & 0 & 0 & 2 & 0 & 0 & $\mathbf{0}$ & 0 & 0 & 0 & 1 & 0 & 0 & 0 & 0 & 1 \\
\hline S. marlothii............. & 0 & 1 & 1 & 1 & 0 & 0 & 0 & 2 & 0 & 0 & 0 & 0 & 0 & 0 & 1 & 0 & $?$ & 0 & 0 & 1 \\
\hline medens & 0 & 1 & 1 & 1 & 0 & 0 & 0 & 2 & 0 & 0 & 0 & 0 & 0 & 0 & 1 & 1 & 0 & $\mathbf{0}$ & 0 & 1 \\
\hline ia brevirostrata & 1 & 0 & 0 & 0 & 1 & 1 & 1 & 0 & 0 & 1 & 1 & 0 & 1 & 1 & 0 & 1 & 1 & 0 & 1 & 2 \\
\hline ustifolia. . & 1 & 0 & 0 & 0 & 1 & 1 & 1 & 0 & 0 & 1 & 1 & 0 & 1 & 1 & 0 & 1 & 1 & 0 & 1 & 2 \\
\hline egalen & 1 & 0 & 0 & 0 & 1 & 1 & 1 & 0 & 0 & 1 & 1 & 0 & 1 & 1 & 0 & 1 & 1 & 1 & 1 & 2 \\
\hline M. speciosa & 0 & 0 & 0 & 0 & 0 & 0 & 0 & 2 & 0 & 0 & 0 & 0 & 1 & 1 & 0 & 1 & 0 & 1 & 1 & 2 \\
\hline M. glauca & 0 & 0 & 0 & 0 & 1 & 1 & 1 & 0 & 0 & 0 & 0 & 0 & 1 & 1 & 0 & 1 & 1 & 0 & 1 & 2 \\
\hline M. lanuginosa & 0 & 0 & 0 & 0 & 1 & 1 & 1 & 0 & 0 & 0 & 0 & 0 & 1 & 1 & 0 & 1 & 1 & 0 & 1 & 2 \\
\hline M. transvaalens & 0 & 0 & 0 & 0 & 1 & 1 & 1 & 0 & 0 & 0 & 0 & 0 & 1 & 1 & 0 & 1 & 1 & 0 & 1 & 2 \\
\hline M. $a$ & 0 & 0 & 0 & 0 & 1 & 1 & 1 & 0 & 0 & 0 & 0 & 0 & 1 & 1 & 0 & 1 & 1 & 0 & 1 & 2 \\
\hline .. & 0 & 0 & 0 & 0 & 1 & 1 & 1 & 0 & 0 & 1 & 0 & 0 & 1 & 1 & 0 & 0 & 0 & 0 & 1 & 2 \\
\hline ifolia & 0 & 0 & 0 & 0 & 1 & 1 & 1 & 0 & 0 & 1 & 0 & 0 & 1 & 1 & 0 & 0 & 0 & 0 & 1 & 2 \\
\hline arginata & 0 & 0 & 0 & 0 & 1 & 1 & 1 & 0 & 0 & 1 & 0 & 0 & 1 & 1 & 0 & 0 & 1 & 0 & 1 & 2 \\
\hline M. galpinii . & 0 & 0 & 0 & 0 & 1 & 1 & 1 & 0 & 0 & 1 & 0 & 0 & 1 & 1 & 0 & 0 & 1 & 0 & 1 & 2 \\
\hline$M . b r$ & 0 & 0 & 0 & 0 & 1 & 1 & 1 & 0 & 0 & 1 & 0 & 0 & 1 & 1 & 0 & 1 & 1 & 0 & 1 & 2 \\
\hline$M, p$ & 0 & 0 & 0 & 0 & 1 & 1 & 1 & 0 & 0 & 1 & 0 & 0 & 1 & 1 & 0 & 1 & 1 & 0 & 1 & 2 \\
\hline M. longip & 0 & 0 & 0 & 0 & 1 & 1 & 0 & 1 & 0 & 2 & 0 & 0 & 1 & 1 & 0 & 1 & 1 & 1 & 1 & 2 \\
\hline M. ignea & 0 & 0 & 0 & 0 & 1 & 1 & 0 & 1 & 0 & 2 & 0 & 0 & 1 & 1 & 0 & 1 & 1 & 0 & 1 & 2 \\
\hline M. drudeana. & 0 & 0 & 0 & 0 & 0 & 0 & 0 & 2 & 0 & 1 & 0 & 0 & 0 & 0 & 1 & 1 & 0 & 0 & 0 & 1 \\
\hline M. deserticola & 0 & 0 & 0 & 0 & 0 & 0 & 0 & 1 & 0 & 1 & 1 & $?$ & 0 & 0 & 1 & 1 & 0 & 0 & 0 & 1 \\
\hline$M$. nived & 0 & 0 & 0 & 0 & 1 & 0 & 0 & 1 & 0 & 1 & 1 & 1 & 0 & 0 & 1 & 1 & 0 & 0 & 0 & 1 \\
\hline M. heliotropioides & 0 & 0 & 0 & $\mathbf{0}$ & $\mathbf{0}$ & 0 & 0 & 1 & 0 & 1 & 1 & 1 & 0 & 0 & 1 & 1 & 0 & 1 & 0 & 1 \\
\hline M. umbellata & 0 & 0 & 0 & $\mathbf{0}$ & 0 & 0 & 0 & 1 & 1 & 0 & 1 & 0 & 0 & 0 & 1 & 1 & 0 & 1 & 0 & 1 \\
\hline M. luederitziana & 0 & 0 & 0 & 0 & 0 & 0 & 0 & 1 & 1 & 0 & 0 & 0 & 0 & 0 & 1 & 1 & 0 & 1 & 0 & 1 \\
\hline M. parvifolia & 0 & 0 & 0 & 0 & 0 & 0 & 0 & 0 & 1 & 0 & 0 & 0 & 0 & 0 & 1 & 1 & 0 & 1 & 0 & 1 \\
\hline M. trilobata . & 0 & 0 & 0 & 0 & 0 & 0 & 0 & 1 & 1 & 0 & 0 & 0 & 0 & 0 & $?$ & 1 & 0 & 0 & 0 & 1 \\
\hline M. ignorata & 0 & 0 & 0 & 0 & 0 & 0 & 0 & 1 & 1 & 0 & 0 & 0 & $?$ & 0 & 1 & 1 & 0 & 0 & 0 & 1 \\
\hline
\end{tabular}




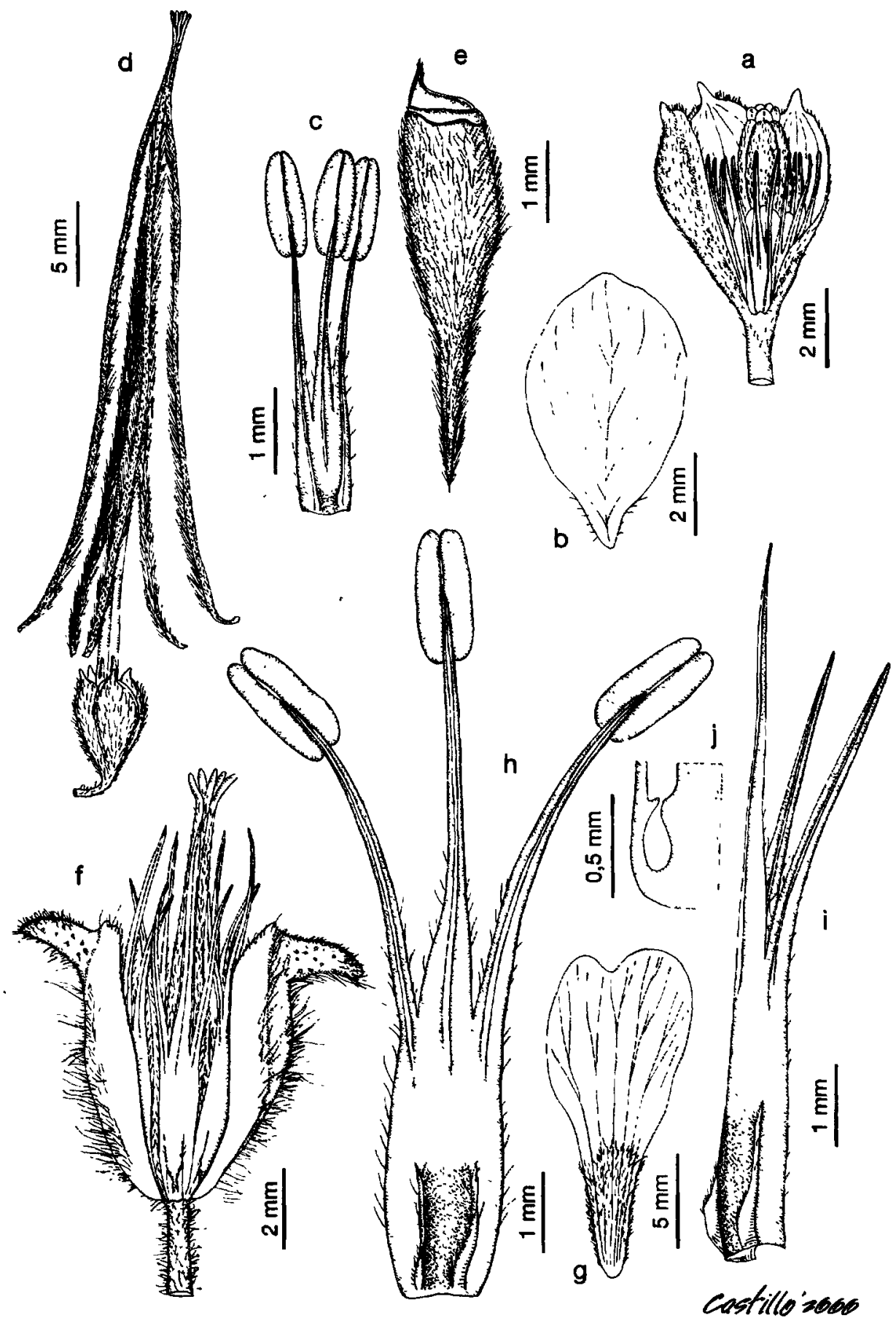

Fig. 1.-Flower and fruit structures in Monsonia nivea (a-e: $L$. Kralik 26, MA 628481) and M. parvifolia (f-j: Schlechter s.n., W). a: flower; b: petal; c: group of stamens; d: schizocarp with the five awns partially separated; $e$ : mericarp body; f: flower; $g$ : petal; $h$ : front view of a group of stamens; i: lateral view of a group of stamens; $j$ : transversal section of nectary including one nectary pouch. 
(perennials); and (3) horizontal, woody or stout rhizomes, often sheathed with old stipules on the base of plant, more or less branched, generally without tubers. Many of the species of Pelargonium have vertical branched roots, while others have tubers. Caulescence is the rule in Monsonia, but some species have a tendency to adopt a rosulate appearance, and the stagnation of growth makes them almost acaulous, such as $M$. deserticola, $M$. drudeana, $M$. heliotropioides, $M$. ignorata, and $M$. nivea. Sarcocaulon are fleshy shrublets covered with waxy bark (tables 2 and 3, characters 2 and 3), features which never occur in Monsonia. The bark is formed by a phellogen; which produces a wide phellem to the outside and several layers of phelloderm cells toward the inside (MOFFETT, 1997). Also, some species of Pelargonium are succulent, but none has a bark impregnate of wax and resin (Moffett, 1997). P. peltatum has a herbaceous habit.

Spines, leaves, leaf shape and venation.-Species of Monsonia lack spines, while in Sarcocaulon the spines are formed from the long petioles after the laminas fall off (tables 2 and 3, character 4) (Moffett, 1997). Leaves are divided only in $M$. speciosa and $M$. longipes. Monsonia speciosa includes lobed, palmate, palmate-lobed, and palmatifid leaves (VENTER, 1979). Two main types of leaf venation can be recognised in Monsonia: subpalmate to palmate, and subpinnate to pinnate, (tables 2 and 3, character 5). Only two species have palmate veins: $M$. drudeana and $M$. ignorata, while in $M$. deserticola, $M$. heliotropioides, $M$. luederitziana, $M$. parvifolia, $M$. trilobata, and $M$. umbellata veins are mostly subpalmate. Pinnate or subpinnate veins are found in all other species of Monsonia. Palmate or almost palmate veins occur in most species of Pelargonium and Sarcocaulon.

Stipules.-A large range of variation of stipule shapes occurs in Monsonia. Twelve species have oval to lanceolate stipules whereas the remaining 13 species have linearlanceolate to subulate stipules. Pelargonium include both linear and lanceolate stipules (tables 2 and 3, character 6). Tuft hairs were found on the stipule apex of 15 species, whereas we did not find this character neither in the remaining 10 species nor in Pelargonium (tables 2 and 3, character 7).

Inflorescences.-Axillar flowering stems are found in all species, being also terminal in some of them. Development of terminal or axillar flowering stems is however not consistent within the same species. There are two significant inflorescence types: cymes and pseudoumbels. Thirteen species of Monsonia have cymes, while 10 species have pseudoumbels, as do most Pelargonium species (tables 2 and 3, character 8). Inflorescence of two Monsonia species bears only a single flower ( $M$. drudeana and $M$. speciosa). Other than the 13 species with cymes, we have observed only monochasial inflorescences, except in $M$. burkeana and $M$. emarginata where they can be both, dichasial and monochasial. Also, all studied Sarcocaulon bear solitary flowers.

Flower symmetry.-All species of Monsonia have actinomorphic flowers (figs. 1a, If, $2 \mathrm{a}$ and 21). On the contrary, all species of Pelargonium are zygomorphic except for $P$. incarnatum (STRUCK, 1997).

Sepals.-Imbricate, persistent sepals are found in all species of Monsonia. Concave sepals retain nectar, being sometimes connate or somewhat enlarged (figs. 1f, 3B and 3C). A group of five species have sepal enlargement at the base in such a way that an appendage encloses an axillar nectary (pouches). This pouch is limited laterally by walls that connect the sepals with the base of the staminal filaments (figs. 4A, 4B and 4C) (tables 2 and 3, character 9). The cavity is covered by hairs (figs. 4D and 4E) and has stomata on the epidermis (fig. 4F). Five representatives of sect. Monsonia (M. umbellata, $M$. parvifolia, $M$. luederitziana and $M$. ignorata) show pouches. Pelargonium and Sarcocaulon lack pouches and sepal or staminal enlargements.

Petals.-Variation in indumentum (hair distribution), colour (white, yellow, pink, mauve, bluish) and size occur frequently within the same species (VENTER, 1979). Several shapes occur: entire, notched, or lobed 


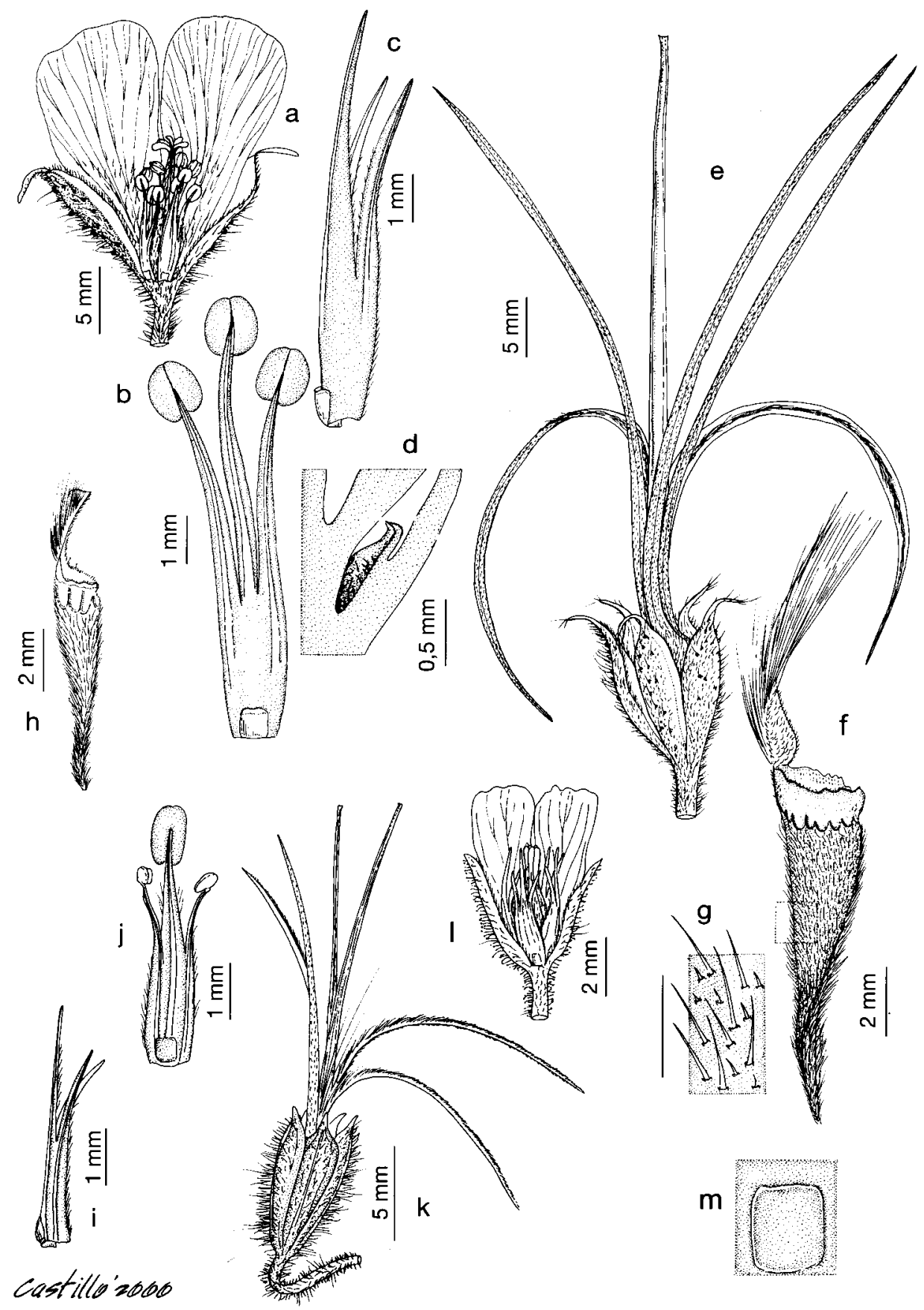

Fig. 2.-Flower and fruit structures in Monsonia longipes and $M$. brevirostrata. a-f: $M$. longipes (Cufodontis 555, W); a: flower; b: front view of a group of stamens; c: lateral view of a group of stamens; d: transversal section of nectary; e: schizocarp with the five awns partially separated; $f$ : mericarp body; $g$ : surface of mericarp body showing long and short bristles; h-m: $M$. brevirostrata (Krook 2220, W); h: mericarp body; i: front view of a group of stamens; j: lateral view of a group of stamens; $\mathrm{k}$ : schizocarp with the five awns partially separated; 1: flower; m: nectary. 
(figs $1 \mathrm{~b}, 1 \mathrm{~g}, 2 \mathrm{a}$ and $2 \mathrm{l})$. Venation varies from 3,5 or multiple veins, within different species or individuals of the same species.

Nectaries.-There are five episepal nectaries in Monsonia, placed on the base of each group of three joint staminal filaments. The nectaries have a secretory parenchyma with intercellular spaces inside and anomocytic stomata generally on its surface (figs $3 \mathrm{~F}, 4 \mathrm{~F}$, $5 \mathrm{C}$ and $6 \mathrm{E}$ ). They are vascularized by branches of phloematic sepal bundles. Usually, the branch that goes to sepal and stamen also reaches the nectary (figs 3E, 4B and 5E). From our anatomical studies we have coded nectaries as two main types considering the position of secretory tissue: (1) axillar nectaries, with secretory tissue at the sepal axile (fig. 3A-E); and, (2) secretory knobs, with prominent tissue (knob) on the base of each group of three joint staminal filaments. The latter type includes two subtypes, one has the secretory tissue on the outer part of the knob and has no hollow inside (fig. 5A-F), and the second has the secretory tissue on the inner part of a hollow located behind the knob, while the external part of knob has no stomata (fig. 6A-F, tables 2 and 3, character 10). The size and shape of the knobs are variable between species. All the types of nectaries are often followed by a shallow channel along the group of filaments, with two rows of hairs which serve to lead the nectar upwards (fig. $1 \mathrm{c}, 1 \mathrm{~g}, 2 \mathrm{j}, 4 \mathrm{D}$ and $4 \mathrm{E})$. The disposition of hairs, the channel and the size of nectaries are variable.

Androecium.-Monsonia has 15 anthers gathered in groups of three filaments, the highest number in the family (VENTER, 1979; YEO, 1990). The stamens form a tube with 5 groups of filaments fused more or less along the length. Here we report for the first time an exception to this pattern in Monsonia for $M$. brevirostrata, which has only 5 fertile stamens plus 10 sterile filaments. Thus, each central anther of the group is fertile, while two lateral anthers abort (fig. $2 \mathrm{j}$ ). Anther size varies in Monsonia. There are seven species with small anthers (less than $1 \mathrm{~mm}$ ) and the remaining eighteen have distinctly long anthers (tables 2 and 3, character 11). Anther size is usually related to pollen content. The pollen content per anther varies in Monsonia. VENTER (1986) reported a striklingly low number of pollen grains in $M$. nivea and $\boldsymbol{M}$. heliotropioides (8-10 per anther), while in most other species it reaches more standard features (i.e. 740-900 grains per anther in $M$. speciosa, counted in this study).

Pollen.-Species of Monsonia sect. Olopetalum have reticulate pollen with large cells (fig. 7G-H), whereas species in M. sect. Monsonia have three types: (1) reticulate with large cells (found in 22 species) (fig. 7A-C and $7 \mathrm{~F}) ;(2)$ reticulate with large cells and supratectal processes, only in $M$. nivea and $M$. heliotropioides (fig. 7E); and (3) striate pollen like in Erodium, which occurs only in $M$. deserticola (fig. 7D). Presence of supratectal processes was coded for the cladistic analysis (tables 2 and 3, character 12). The Erodiumtype pollen has been found only once in $M$. deserticola and thus it was not considered in the cladistic analysis. Other details, not coded in the analysis, are the externally serrate tectum in $M$. speciosa and the slightly wavy and dense muri in $M$. drudeana, M. luederitziana, $M$. parvifolia, and $M$. umbellata. Pollen in Sarcocaulon is similar to type 1 in Monsonia, while in Pelargonium it is very variable, and in $P$. peltatum is also reticulate, but with smaller cells (STAFFORD \& GibBY, 1992). Most of these types of pollen in Monsonia have been reported by BORTENSCHLAGER (1967) and VERHOEVEN \& VENTER (1986).

Gynoecium.-The ovary is superior, terminally beaked, 5-lobed, and 5-locular. Each carpel contains 2 axilar, campylotropous ovules, the lower being abortive (NARAYANA \& ARORA, 1963; BoESEWINKEL \& BEEN, 1979; BOESEWINKEL, 1997). The style is obsolete, with 5 stigmata, linear or clavate, or rarely short and ovoid or rounded (fig. 8A and $8 B$ ). The ovary base has sometimes tubular hairs with basal glands, which produce a smelling secretion. Other species have verrucate (i.e. M. nivea) (fig. $8 \mathrm{D}$ ) or glandular hairs (i.e. M. senegalensis) (fig. 8C and $8 F$ ) on the top of the ovary. The glandular hairs can suffer a transformation or perdure until fruit maturation (fig. 8E). The tip of 

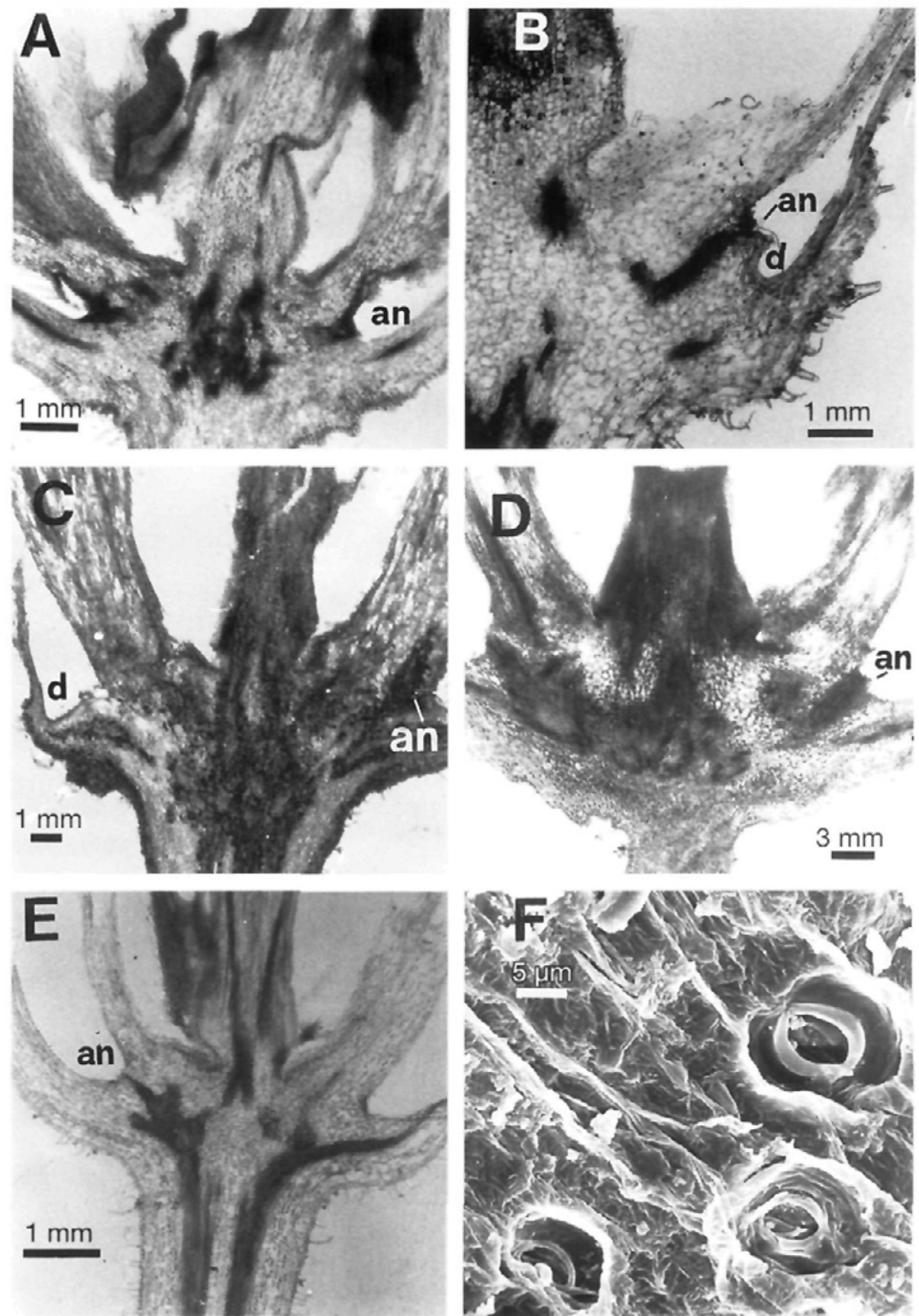

Fig. 3.-Light and SEM micrographs of axillar nectaries in the species of Monsonia without pouches. A: Thin-section of $M$. transvaalensis with axillar nectaries (an) (Wendermann \& Oberdieck 2155, P). B: M. lanuginosa and a small depression (d) formed by the sepal (Wendermann \& Oberdieck 2155, P). C: M. attenuata showing axillar nectaries (an), and cavity (d) formed by the sepal (Gerrard 1431, W). D: M. speciosa showing axillary nectaries (an) (Marloth s.n., W). E: Light micrograph of $M$. glauca showing axillary nectaries (an), (K. Dinter 5655, P). F: SEM micrograph of nectariferous surface of $M$. attenuata showing stomata (Gerrard $1431, \mathrm{~W}$ ). 
glandular hairs has special structures to secrete substances (fig. 8C, 8F and 9A). Ovary ornamentation is either highly variable or typical ones are present in only a single species, which makes this character not useful for cladistic analyses.

Fruit.-It is a rostrate schizocarp with 5 mericarps. The mericarps are tailed on the top, the awn being as long as the schizocarp beak. When the mericarp is ready to be dispersed the tail detaches from the central axis (columella) (YEO, 1984, 1990). We have coded this character into two states depending on awn detaching: (1) in Monsonia sect. Olopetalum, the upper part of the tail separates along the columella and then the mericarp body (fig. 2e); (2) alternatively, in Monsonia sect. Monsonia the distal part of the awn remains attached to the columella while the mericarp body detachs (fig. 1d) as in Sarcocaulon and Pelargonium (tables 2 and 3, character 13). After mericarp detachment, the awn becomes twisted and some hairs become visible on the internal surface to facilitate the mericarp dispersal by the wind or other means. The columella in sect. Olopetalum is short and stout while in sect. Monsonia is very long and weak (tables 2 and 3, character 14). Although one of the outgroups (Sarcocaulon) has long and weak columella, Pelargonium peltatum has a stout columella. This character needs a detailed study in Pelargonium.

Awn.-All representatives of Geraniaceae have hairs on the inner part of the awn. These hairs are similarly long on both the lower and upper parts in sect. Monsonia (plumose awns of Boissier's sect. Plumosae), whereas they are long on the lower part but short on the upper in sect. Olopetalum (not plumosae awns of Boissier's sect. Barbatae; table 1). Monsonia trilobata (sect. Monsonia) is an exception because it has not plumose awns (tables 2 and 3, character 15). Most species of Pelargonium are not plumose, while all studied Sarcocaulon are plumose. Awn fibres suffer changes in length when moist, causing mericarp rotation that helps to bury the mericarp (fig. 9C and 9F; CoBELLI, 1892).

Mericarp body.-There is an abscission point where the mericarp body and the awn are detached in maturity (fig. 9D and 9F). The mericarp body has two morphologies: \pm conic, tapered to the awn in a group of four species (M. emarginata, $M$. galpinii, $M$. natalensis, and $M$. grandifolia) (fig. $10 \mathrm{G}-\mathrm{H}$ ), and abruptly narrowed into the awn in the rest (fig. 1e, 2h, 2f, 10A-F, and 10I-J; tables 2 and 3 , character 16). The mericarp is tapered in Sarcocaulon crassifolium, S. marlothii and Pelargonium peltatum.

There are two types of structures on the mericarp near the abscission point: ridges and pits (figs. 9D, 9F-G, 10A-F and 10J). Pits are concavities situated symmetrically on both sides of the upper part of mericarp. that have glands or other secretory devices (figs. 10A, $10 \mathrm{~F}$ and $10 \mathrm{~J}$ ). Pits are formed by collapsing several layers of developed exocarp cells (fig. $9 \mathrm{~F}, \mathrm{G})$. The pit is obscure or absent in some species of Monsonia sect. Monsonia, such as in $M$. deserticola, $M$. heliotropioides, $M$. ignorata and $M$. nivea (fig. 9D and 10I). One or two transverse ridges may or not be present on the upper part of the mericarp body (figs. 9D, 10C-E). These characters were not used due to high variability observed in both pits and ridges in Monsonia.

Indumentum.-Mericarp indumentum is formed by many types of hairs. A comprehensive classification of them was reported by Venter (1990). There are four main types: (1) gland based hairs (fig. 9B); (2) stalked glands (= gland-tipped hairs; fig. 8C, 8E and 9A), which can be columnar, straight acicular and curved acicular; (3) sessile or punctate glands (fig. $11 \mathrm{I}$ ); and eglandular hairs (fig. 9C, 11AJ, 12A-H). The eglandular hairs are uni- or pluricellular. An important type of stout pluricellular hairs is the bristle. This has a basal bulb, a narrowed cell, and a long cylindrical cell (figs. 11G and 12E). Its surface can be smooth, striate or granulate; granulate bristles could increase mericarp adherence (figs. 11B$\mathrm{C}, 11 \mathrm{~F}, 11 \mathrm{H}$ ). The bristle tip is acute, rounded or truncate (figs. 11C, 12B, 12G). Thirty species have long bristles of similar length (fig. 12A-D, 12F-H), whereas the remaining species have short and long bristles on the mericarp (fig. 11E-F) (tables 2 and 3, character 17). Similar, long bristles cover the meri- 

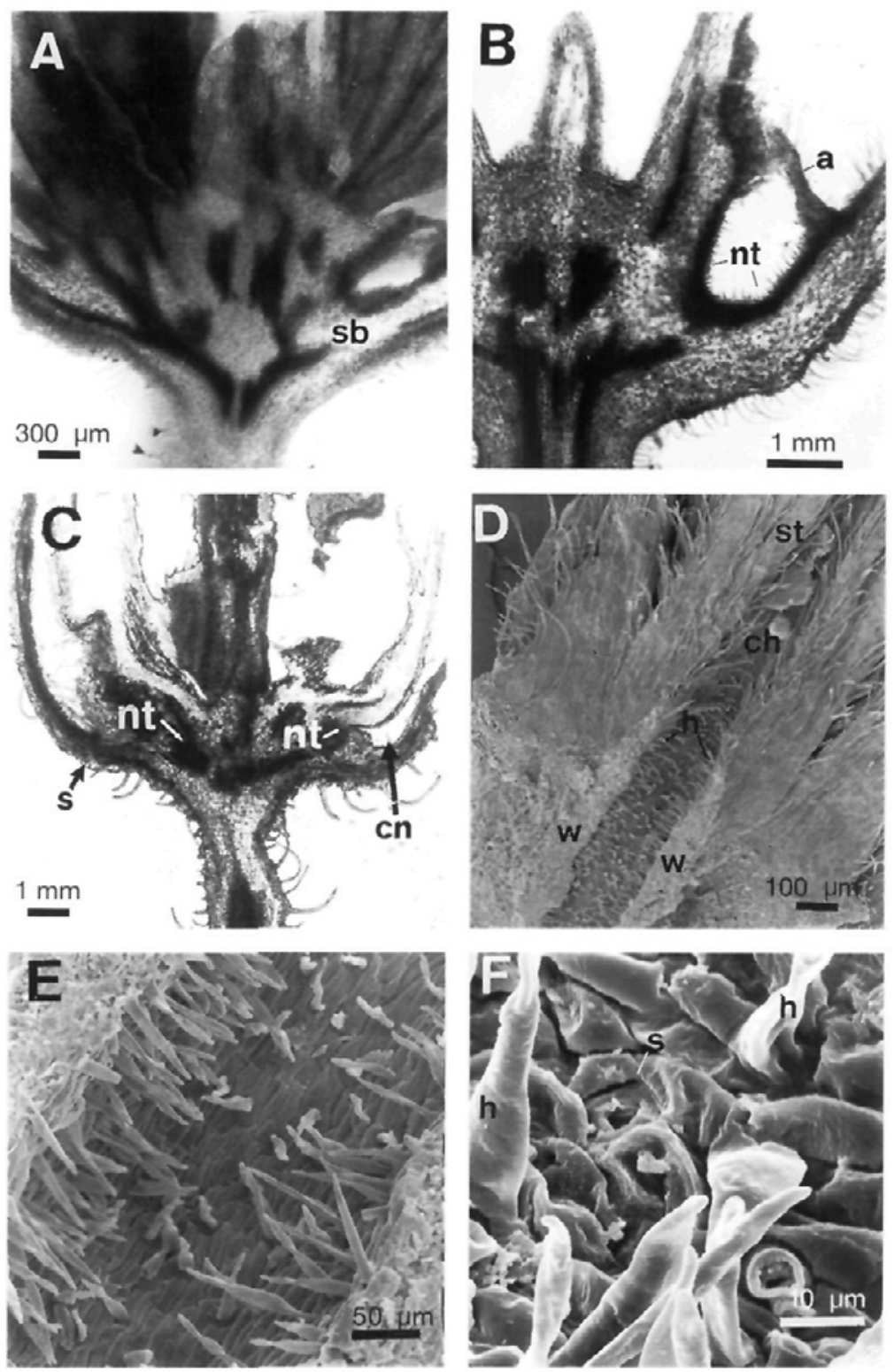

Fig. 4.-Light and SEM micrographs of axillar nectaries with the sepals and the receptacle enlarged forming a pouch. A: Thin-section of Monsonia umbellata flower showing the cavity formed by sepals and receptacle. The sepal bundle (sb) progress close below the nectary ( L.W. Carisso \& F. Sousa 243, COI). B: Thin-section of M. luederitziana flower showing the cavity formed by sepals and receptacle formed by enlarged sepals which have an appendage to close it (a); the nectariferous tissue (nt) is stained in the surface of the cavity. It is covered by hairs and connected with the sepal bundle (Schlieben $8806, \mathrm{~W}$ ). C: Thin-section of $M$. parvifolia flower showing the cavity formed by sepals (s) and receptacle (cn) and the nectariferous tissue (nt) (Schlechter s.n., W). D: SEM imicrograph of nectary of $M$. parvifolia showing the cavity formed between the base of a stamens group (st) and the sepals; two walls (w) connect the stamen filaments with the sepals and close the cavity. The nectary is followed by a channel (ch) along the group of filaments, with two rows of hairs (h), which lead the nectar upwards. E: SEM micrograph of nectary of M. parvifolia showing this cavity covered with hairs. F: SEM micrograph of surface of $M$. parvifolia nectary showing one stoma (s) and hairs (h) (Schlechter s.n., W). 

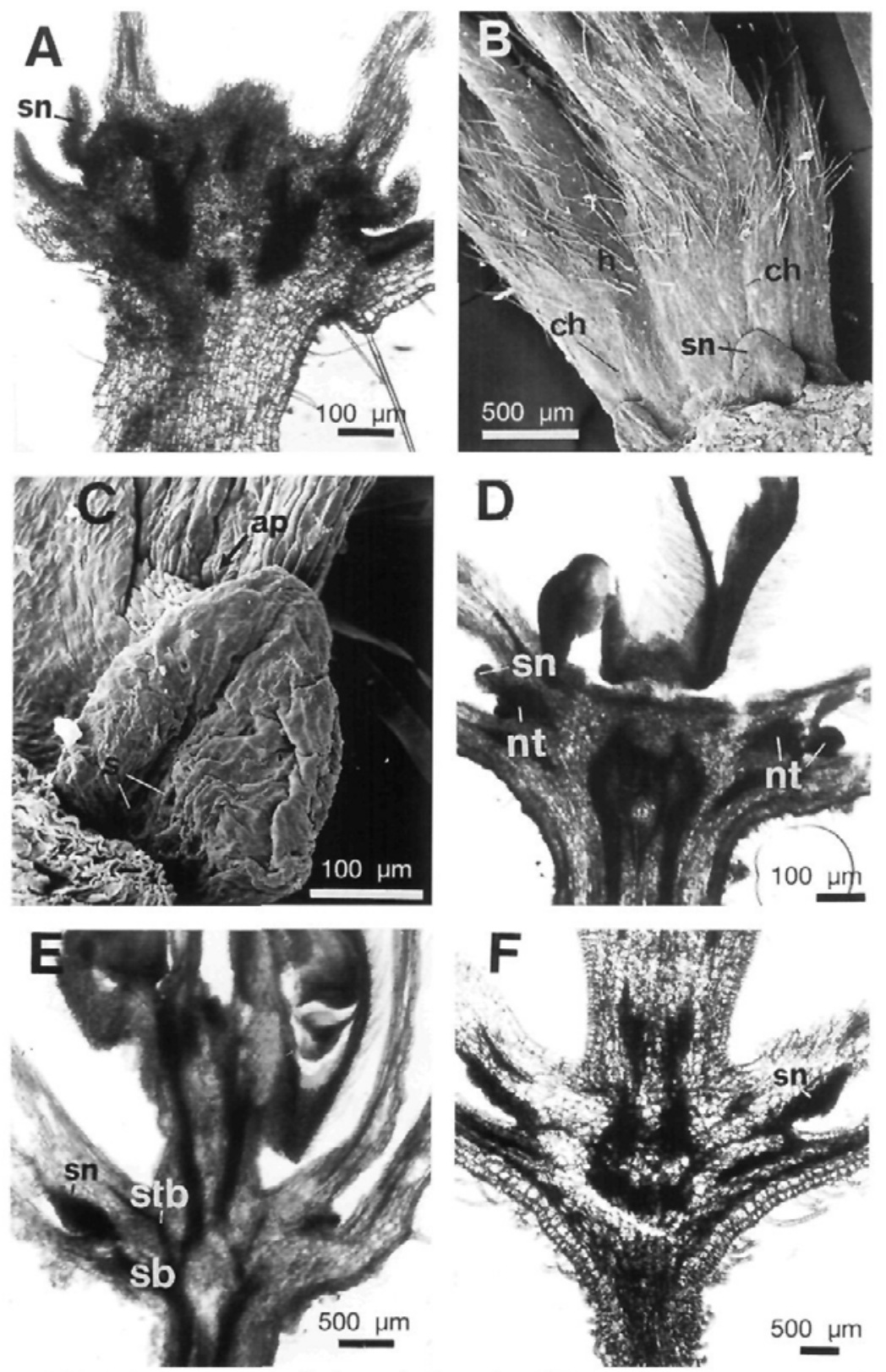

Fig. 5.-Light and SEM micrographs of staminal nectaries in species of Monsonia showing nectary protuberance without nectariferous tube. A: Thin-section of $M$. grandifolia flower; the nectaries form a long protuberance with the secretory tissue in all the surface (sn) (H. Rudatis 1342, W s.n.). B: SEM micrograph of base of stamen filaments and nectary of $M$. natalensis. The nectary form a protuberance at the base of each stamen group (sn) which has a channel (ch) where the nectar rise, being latter retained on the hairs (Kuntze s.n., P). C: SEM micrograph of antisepal side of $M$. natalensis nectary, showing aperture on the nectary top (ap), nectariferous tissue is only on the antisepal side. The base contains most of stomata; the interior has no stomata (s) serving to retain nectar (Kuntze s.n., P). D: Light micrograph of M. emarginata showing staminal nectaries (sn) and the nectariferous tissue (nt) (Penther 2174, W). E: Light micrograph of $M$. brevirostrata showing staminal nectaries (sn) and the bundles of stamen (stb) and sepal (sb) (Krook 2220, W). F: Light micrograph of $M$. nivea showing staminal nectaries (sn) (L. Kralik 26, MA 628481). 

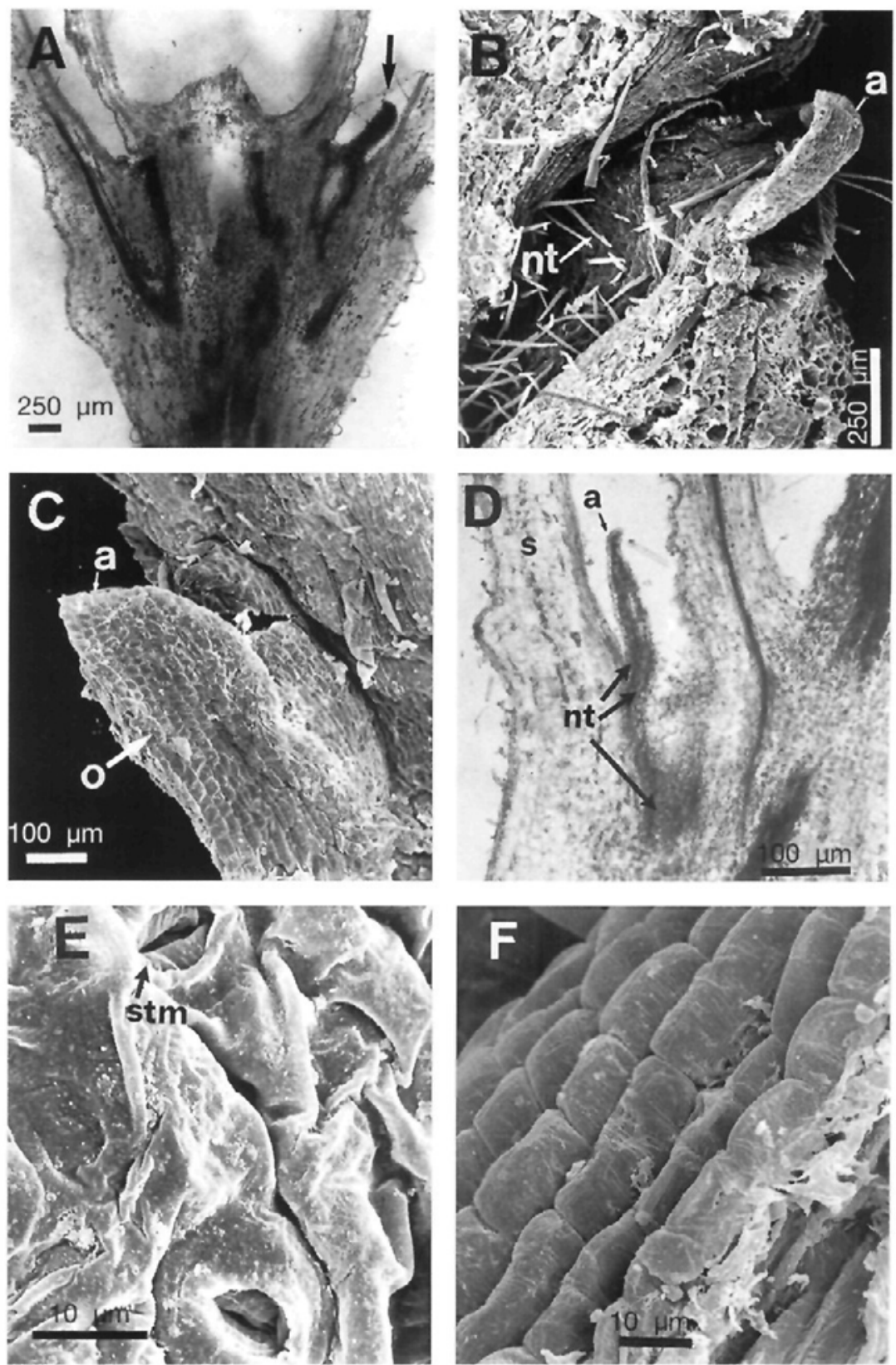

Fig. 6.-Light and SEM micrographs of staminal nectaries in species of Monsonia showing a protuberance with nectariferous tube. A: Light micrograph of $M$. longipes flower. The nectaries are protected by an appendage (arrow) attached to stamen filament with a conic cavity inside. The secretory tissue is on the inner surfaces of the cavity (nt) and the appendage (a) (Cufodontis 555, W). B: SEM micrograph of a section of $M$. longipes nectary showing the nectariferous surface (nt) and the sepal appendage (a) (Cufodontis 555, W). C: SEM micrograph of appendage of $M$. longipes nectary (a) showing the outer surface (o) of sepal appendage (a) (Cufodontis 555, W). D: Light micrograph of a section of $M$. longipes nectary showing the secretory tissue on the basal surfaces of the cavity (nt), and the appendage. E: SEM micrograph of inner surface of nectary, which has stomata (stm) (Cufodontis 555, W). F: SEM micrograph of outer surface of nectary, which has no stomata (Cufodontis 555, W). 
carp body in all species of Pelargonium and Sarcocaulon.

Ornamentation.-Mericarp surface includes two ornamentation types: reticulate in which polygonal exocarpic cells form a net (i.e. Monsonia deserticola and M. nivea) (fig. $12 \mathrm{C}$ and $12 \mathrm{~F}$ ); and non-reticulate ornamentation with \pm irregular cells $(M$. luederitziana and $M$. emarginata) (fig. $11 \mathrm{~J}$ and $12 \mathrm{H}$ ). In both cases, periclinal cell walls vary from concave to convex or papillary, including sloped or globose papillae (fig. $11 \mathrm{H}, 12 \mathrm{H}$ ). Conversely, the anticlinal walls are often wavy (fig. 12F). Sometimes, exocarp cells collapse giving a planate surface, but the papilla outline remains visible (figs. 11A, 11B, 11J). Mericarps with sloped papillae have bristles surrounded by semicircular rims called "pockets", which are formed by fusion of these papillae and show a wide morphological variation (figs. 11B, 11F, 11I, 12A, 12B,
12D, 12H) (tables 2 and 3, character 18). These pockets prevent the bristle from returning. All tested species of Pelargonium and Sarcocaulon lack these pockets.

Mericarp wall.-Two types of mericarp wall exist in Monsonia: the widest walls (about $40-70 \mathrm{~mm}$ wide) were found in sect. Olopetalum, having a sclerenchymatose part (15-30mm wide) of 3-5 layers of cells (fig. 11D, 11G), while sect. Monsonia and Pelargonium have narrower walls $(20-30 \mathrm{~mm}$ wide), with a sclerenchymatose region (2-10 mm wide) of usually 1-3 cell layers (fig. 12A, 12E; tables 2 and 3, character 19). The mesocarp layer is also wider in sect. Olopetalum (figs. 9E, 9H, 11D, 11G, 12A, 12E).

Seeds.-Cotyledons are flat and incumbent in Pelargonium (fig. 13A) while they are folded and accumbent in Monsonia (Fig. 13B-D) (Hegelmaier, 1899; Yeo, 1990). However, the degree of cotyledon folding di-
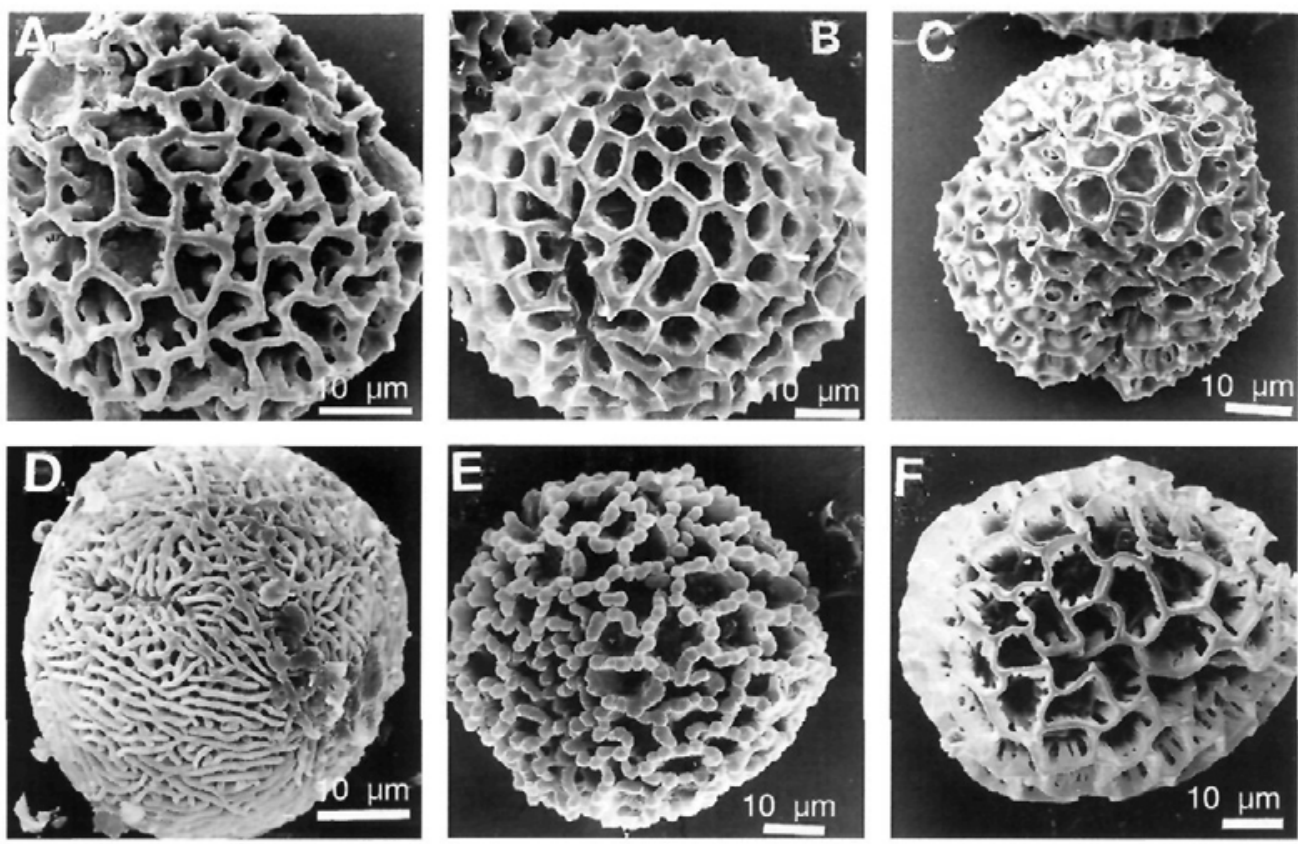

Fig. 7.-Scanning electron micrographs of Monsonia pollen. A: Pollen of M. transvaalensis, reticulate with large cells (6-10 mm of diameter) (Wendermann \& Oberdieck 2155. P). B: Pollen of M. speciosa, reticulate with large cells (6-10 mm of diameter) (Marloth s.n.. W). C: Pollen of M. ignorata, reticulate with large cells (10-16 mm of diameter) (Lavramos \& Pehlemann 19639, MO s.n.). D: Pollen of M. deserticola, striate, similar to pollen of Erodium (Dinter 6611, P). E: Pollen of $M$. nivea, reticulate with large cells (8-11 mm of diameter) and supratectal processes (L. Kralik 26, MA 628481). F: Pollen of M. luederitziana, reticulate with large cells (9-14 mm of diameter) (Schlieben 8806, W). 

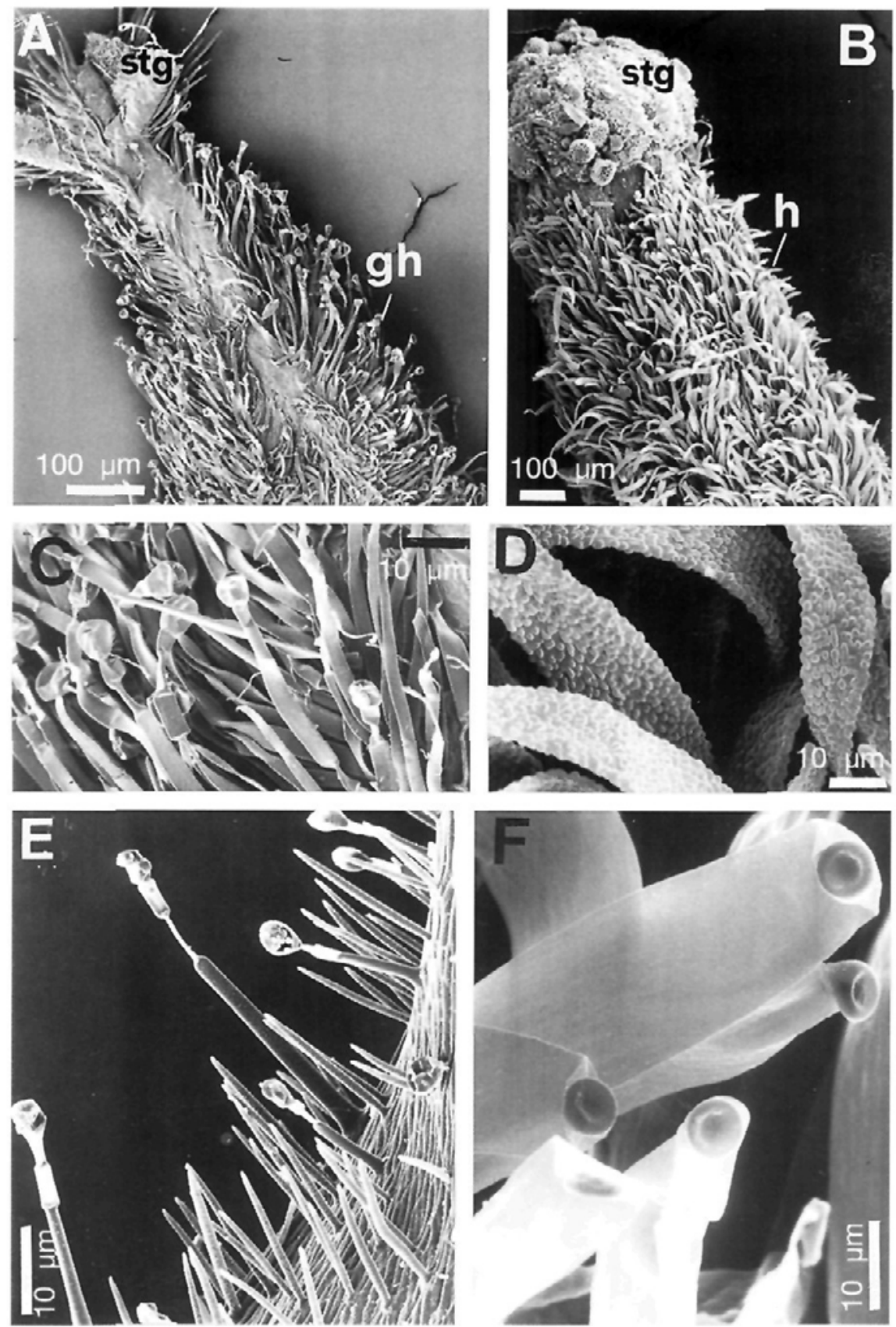

Fig. 8.-Scanning electron and light micrographs of hairs on gynoecia of Monsonia . A: SEM micrograph of $M$. senegalensis gynoecium, which has clavate stigmata $(\mathrm{stg})$ and long glandulose hairs (gh) (G. Cardoso de Matos 6269 , MA 498297). B: Micrograph of M. heliotropioides gynoecium, with short, ovate stigmata (stg) and short hairs (h) (Rechinger 27633, W). C: SEM micrograph of glandulose hairs of $M$. senegalensis gynoecium. D: Micrograph of verrucate hairs (vh) of $M$. heliotropioides gynoecium. E: SEM micrograph of glandulose hairs on the top of $M$. brevirostrata mericarp (Krook 2220, W). F: SEM micrograph of gynoecium hairs of $M$. angustifolia, showing the umbilicate tip structure (Penther 2218, W). 
vides Monsonia into two groups: sect. Monsonia contains 9 species with folded, nonconduplicated cotyledons (fig. 13B-C), and sect. Olopetalum includes 16 species with conduplicate cotyledons, one half of each cotyledon lying on the primary fold of the opposite cotyledon (fig. 13D) (tables 2 and 3, character 20). In Sarcocaulon cotyledons are folded, in a similar fashion to Monsonia sect. Monsonia

Chromosome number.-There are few chromosome counts in Monsonia, most of them reported by WARBURG (1938) and HAIFA \& JOUMENA (1991). The somatic numbers are 22 for M. senegalensis (sect. Olopetalum) (WAR-
BURG, 1938), 26 for $M$. nivea, and 18 for M. heliotropioides (sect. Monsonia) (HAIFA \& Joumena, 1991). According to ALBERS (1996), Monsonia has $x=8,9,10,11,12$, but he did not indicate which species were studied. In Sarcocaulon base number is $x=11$ (Albers, 1990).

\section{Cladistic analysis}

The cladistic analysis using Pelargonium and Sarcocaulon as outgroups, yielded 9 minimal length cladograms consisting of 37 steps, a consistency index (CI) of 0.621 , a retention index $(\mathrm{RI})$ of 0.913 , a rescaled consis-
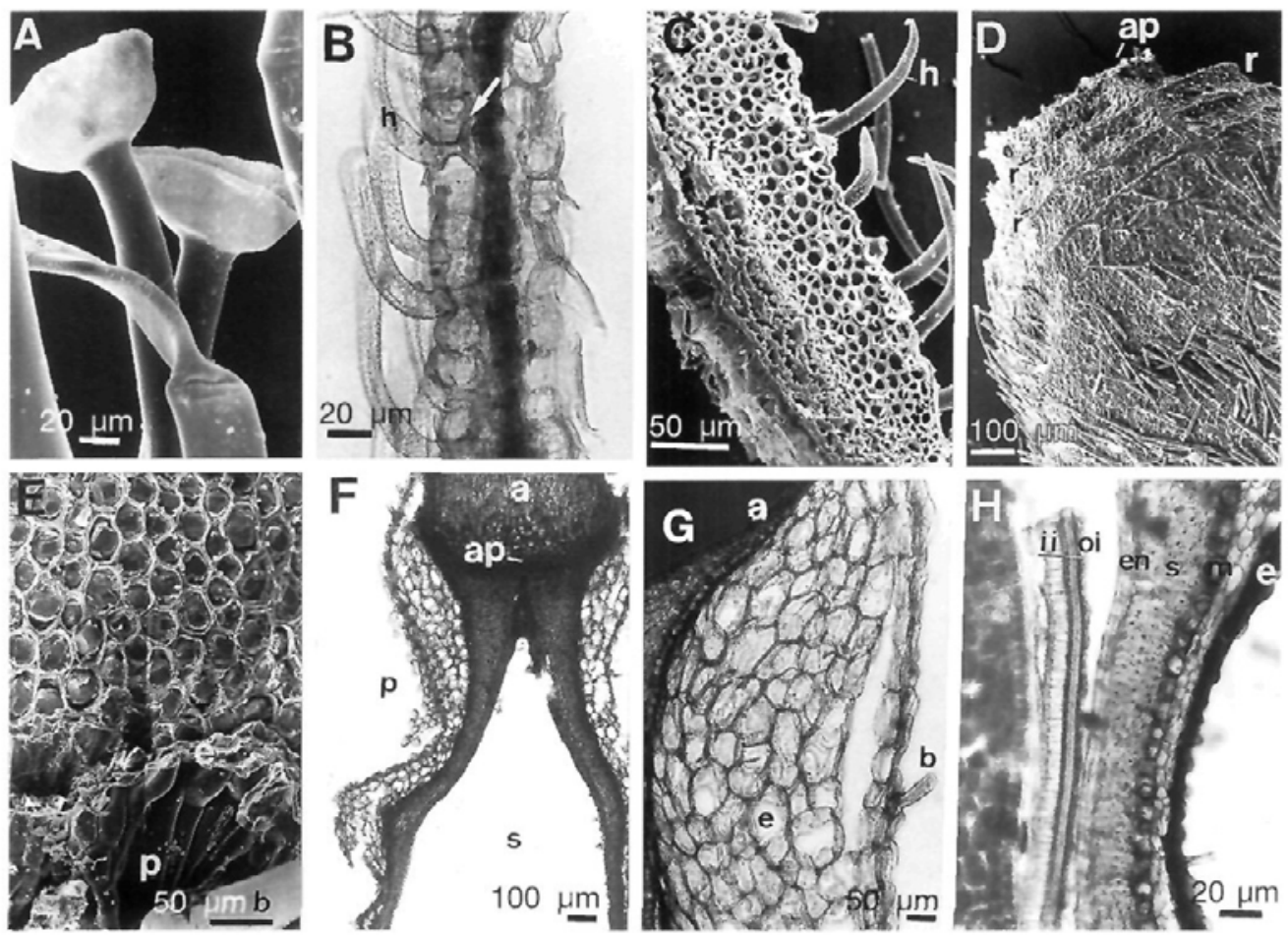

Fig. 9.-Light and scanning electron micrographs of glands and mericarps of Monsonia sect Olopetalum. A: SEM micrograph of glandular hairs on the surface of a pedicel of $M$. angustifolia (Penther 2218). B: Light micrograph of mericarp wall of $M$. nivea (L. Kralik 26, MA 628481). C: SEM micrograph of a section of the awn of $M$. burkeana showing fibres inside, which are hygroscopic (h: hairs) (T. T. Heany 23, COI). D: SEM micrograph of a mericarp of $M$. nivea with ridges (r) and the abscission point of the awn (ap) (L. Kralik 26, MA 628481). E: SEM micrograph of mesocarp cells of $M$. deserticola after separation of the exocarp (p: pocket, b: bristle). F: Light micrograph of a section of $M$. brevirostrata mericarp (a: awn, ap: abscission point of the awn) (s: seed space; p: pit) (Krook 2220, W). $\mathrm{G}$ : Light micrograph of a section of $M$. brevirostrata mericarp; e: cells of exocarp on the pit; b: bristle. H: Light micrograph of a section of the mericarp wall and seed testa in $M$. attenuata (en: endocarp; s: schlerenchima; m: mesocarp; e: exocarp; ii: inner integument of testa; oi: outer integument of testa) (Gerrard 1431. W). 
tency index (RC) of 0.567 , and a homoplasy index (HI) of 0.378 . The strict consensus tree recovers two major clades (fig. 14), one of these clades includes some of the outgroups (Sarcocaulon). The first major clade consists of all species of $M$. sect. Olopetalum and is defined by three synapomorphic characters from the mericarp: mode of detaching (character 13), wall width (character 17), and cotyledon folding (character 20). This clade is supported by $85 \%$ bootstrap. Monsonia speciosa is sister to the rest of the species of $M$. sect. Olopetalum (88\% bootstrap) (subclade I), as a result of one synapomorphy (plane stipules, character 6).
A terminal, well-supported subclade (87\% bootstrap) (subclade IV) is formed by the three annual species ( $M$. brevirostrata, $M$. angustifolia, $M$. senegalensis). Three weakly supported subclades are also found within the sect. Olopetalum: one formed by $M$. brevirostrata$M$. senegalensis- $M$. angustifolia- $M$. natalensis-M. grandifolia- $M$. emarginata- $M$. galpinii- $M$. praemorsa- $M$. burkeana- $M$. glauca-M. lanuginosa- $M$. atenuatta- $M$. transvaalensis ( $78 \%$ bootstrap) (subclade II) which have a tuft of hairs on the stipules (character 7). Monsonia longipes, and M. ignea (66\% bootstrap) (subclade III), are defined by staminal knob-like nectaries, with a conic tube
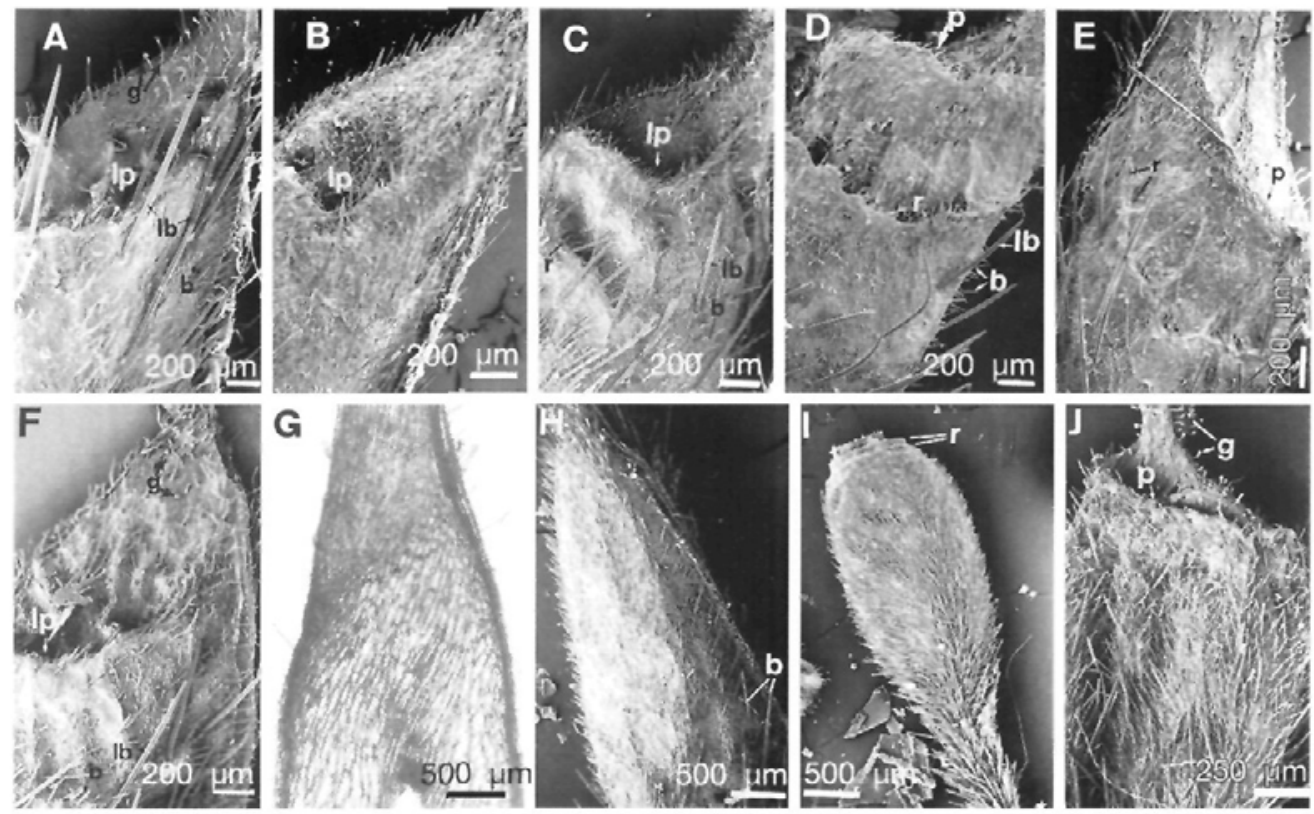

Fig. 10.-Scanning electron and light micrographs of Monsonia mericarps. A: SEM micrograph of a $M$. brevirostrata mericarp, with lateral pit (lp) with glandulose hairs (g) and two types of bristles: short (b) and long (Ib) (Krook 2220, W). B: SEM micrograph of a M. burkeana mericarp, with lateral pit (lp) with glandulose hairs and two types of bristles: short (b) and long (lb) (T. T. Heany 23, COI). C: SEM micrograph of a M. lanuginosa mericarp, with a lateral pit (lp) with sparse glandulose hairs, one slight lateral ridge (r) and two types of bristles: short (b) and long (lb) (Slechter 1308, COI). D: SEM micrograph of a $M$. angustifolia mericarp, with a perpendicular pit (p) with no visible glandulose hairs, one lateral ridge ( $r$ ) and two types of bristles: short (b) and long (lb) (Penther 2218, W). E: SEM micrograph of a $M$. longipes mericarp, with a nearly perpendicular pit (p) with not visible glandulose hairs, one lateral ridge ( $\mathrm{r}$ ) and two types of bristles: short (b) and long (lb) (Cufodontis 555, W). F: SEM micrograph of a $M$. ignea mericarp, with a lateral pit (lp), glandulose hairs $(\mathrm{g})$, wavy mericarp surface and two types of bristles: short (b) and long (lb) (Puccioni \& Stefanini 959, P). G: Light micrograph of a thin section of a gradually tapered mericarp in $M$. emarginata (Penther 2174, W). H:. SEM micrograph of mericarp in $M$. emarginata with only short bristles (Penther 2174, W). I: SEM micrograph of a mericarp in $M$. nivea which has two ridges ( $r$ ) beside the awn $(L$. Kralik 26, MA 628481). J: SEM micrograph of a mericarp in $M$. umbellata which has a glandulose pit (p) and awn insertion (g) (L.W. Carisso \& F. Sousa 243. COI). 
(character 10). Monsonia natalensis, M. grandifolia, M. emarginata, M. galpinii $(59 \%$ bootstrap) form subclade $\mathrm{V}$, nested in subclade II and characterised by tapered mericarps (character 16).

The second major clade (76\% bootstrap) includes the species of sect. Monsonia and the three species of Sarcocaulon forming a politomy. The clade is defined by two synapomorphies: folded, but non-conduplicated cotyledons (character 20) and plumose awns (character 15). There is also a weakly supported subclade formed by $M$. deserticola- $M$. niveaM. heliotropioides (subclade VI) supported by an non-synapomorphic change (anthers very small, shorter than $1 \mathrm{~mm}$, character 11 ). The three species of Sarcocaulon form a clade ( $96 \%$ bootstrap) defined by three synapomorphies: stems fleshy and covered with waxy bark (characters 2 and 3 ) and spines formed from petioles of long leaves (character 4).

\section{DISCUSSION}

\section{Monophyly of Monsonia}

Monophyly of Monsonia is challenged by the inclusion of Sarcocaulon in a clada togeth-
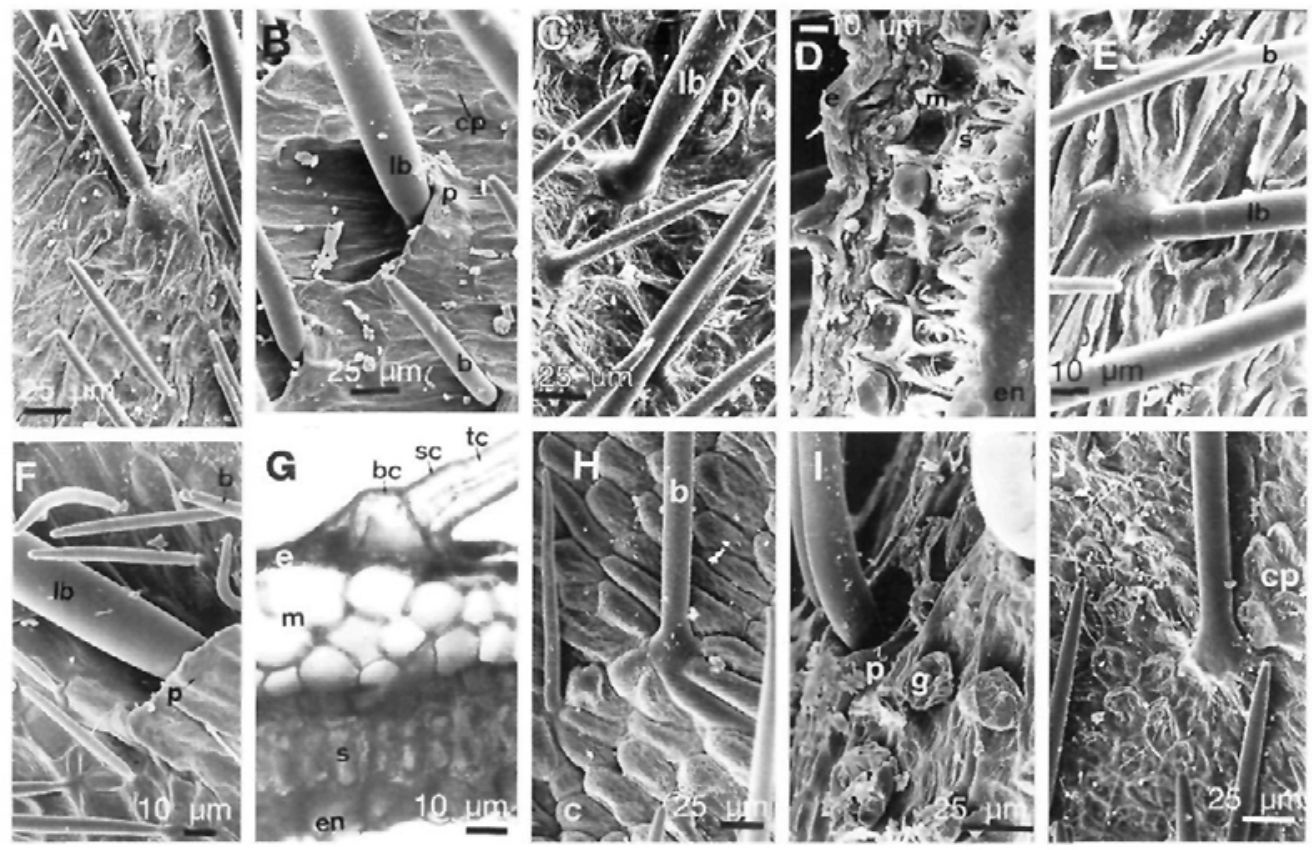

Fig. 11.-Light and scanning electron micrographs of mericarp surfaces of Monsonia sect. Olopetalum. A: SEM micrograph of mericarp surface of $M$. attenuata showing collapsed papillae and two types of bristles (Gerrard 143I, W). B: SEM micrograph of mericarp surface of $M$. longipes showing collapsed papillae (cp), pockets rounding the base of bristles ( $p$ ) and two types of bristles, short (b) and long (lb) (Cufodontis 555, W). C: SEM micrograph of mericarp surface of $M$. burkeana showing collapsed papilles (p), and short (b) and long (lb) bristles with granulate surface and without pockets (Dinter 6611, P). D: SEM micrograph of mericarp wall section in $M$. brevirostrata, showing exocarp (e), mesocarp (m), schlerenchima region (s) and endocarp (en) (Krook 2220, W). E: SEM micrograph of mericarp surface of $M$. brevirostrata, showing a reticulate pattern (without pockets), covered by wax and with two types of bristles: short (b) and long (lb). F: SEM micrograph of mericarp surface of $M$. senegalensis showing pockets (p) only at the base of long bristles (lb), lacking in short bristles (b) (G. Cardoso de Matos 6269. MA 498297). G: Light micrograph of a mericarp wall section of $M$. emarginata showing exocarp (c), schlerenchima region (s), endocarp (en), basal cell of the bristle (bc), second cell of the bristle (sc) and tubular cell of the bristle (tc) (Penther 2174, W). H: SEM micrograph of $M$. emarginata showing a reticulate pattern with convex cells (c) and a single type of bristles without pockets (b) (Penther 2174, W). I: SEM micrograph of mericarp surface of $M$. speciosa showing small glands (g), and bristles with pockets (p) (Marloth s.n., W). J: SEM micrograph of mericarp surface of M. lanuginosa showing collapsed papillae (cp) (Slechter 1308, COI). 
er with Monsonia sect. Monsonia. Thus, ALBERS' (1996) criterion that Sarcocaulon should be included in Monsonia is supported by our analysis based on morphological characters. However, according to MofFETT (1997) these changes could be premature and cause nomenclatural instability. At the present status of knowledge we prefer to maintain Sarcocaulon as a separate genus, until more independent evidence is available.

\section{Cladistic Analysis and Classification of Monsonia}

The results obtained from the cladistic analysis are in agreement with the division of Monsonia into two groups: $M$. sect. Olopetalum (= Barbata) and $M$. sect. Monsonia $(=$ Plumosa $)($ Venter, 1979) $($ table 1). Two species (M. longipes and $M$. speciosa) were placed in sect. Monsonia by Venter (1990) and VERHOEVEN \& VENTER (1986) based on a cluster analysis of morphological characters. However, these two species share the three synapomorphies of $M$. sect. Olopetalum (mode of detaching, wall width, columella consistency, and cotyledon folding), and thus fail within the clade of this section. (tables 2 and 3 ).

In contrast, $M$. sect. Monsonia is only defined by two synapomorphies: folded, but
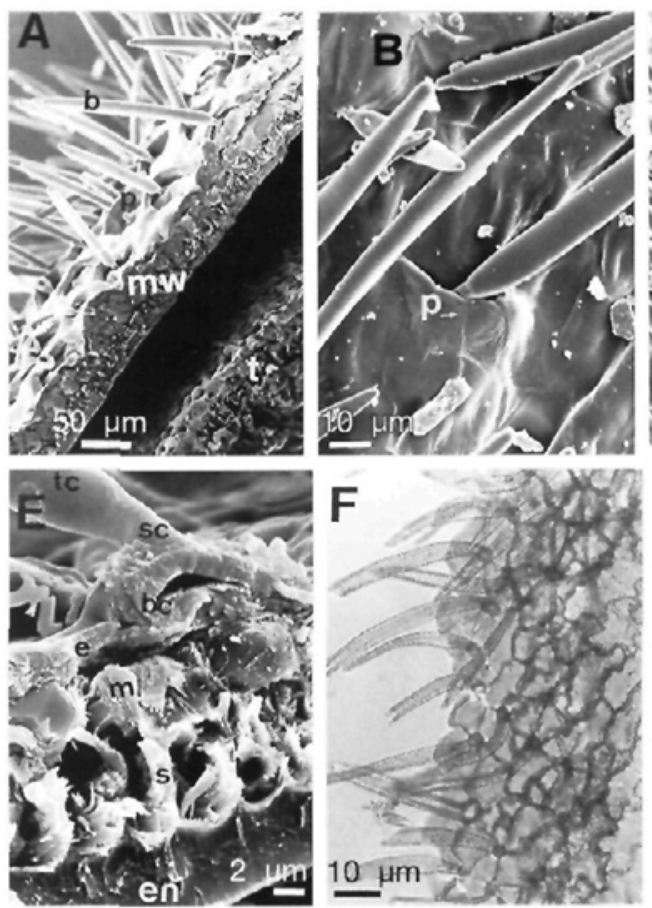
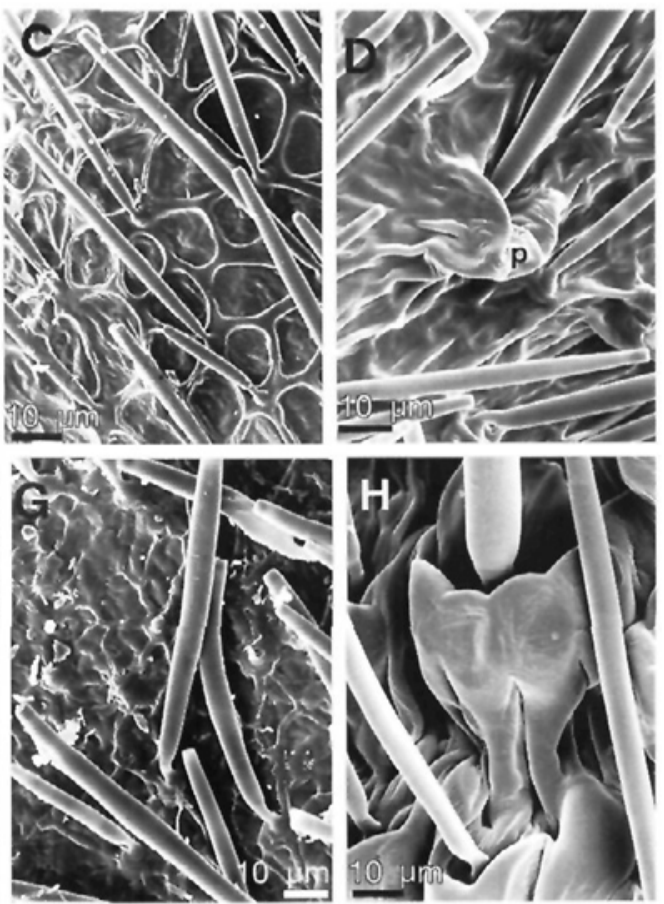

Fig. 12.-Scanning electron micrographs of mericarp surface of Monsonia sect. Monsonia. A: SEM micrograph of a section of mericarp of $M$. luederitziana showing large papillae and pockets (p) surrounding the base of bristles (b). Mericarp wall: mw, and seed testa: $\mathrm{t}$ (Schlieben 8806 , W). B: SEM micrograph of mericarp surface of $M$. parvifolia showing pockets rounding the base of bristles (p) (Schlechter s.n., W). C: SEM micrograph of mericarp surface of $M$. deserticola showing a reticulate pattern with concave cells, and bristles without pockets. (Dinter 6611, P). D: SEM micrograph of mericarp surface of $M$. heliotropioides, showing pockets ( $p$ ) rounding the base of bristles (Rechinger 27633 , W). E: SEM micrograph of a mericarp wall section with a bristle insertion in $M$. nivea, showing exocarp (e), schlerenchima region (s), endocarp (en), basal cell of the bristle (bc), second cell of the bristle (sc) and tubular cell of the bristle (tc) (Kralik 26, MA 628481). F: Light micrograph of separate exocarp layer of $M$. nivea fruit showing wavy cells and the bristle insertion. G: SEM micrograph of mericarp surface of $M$. nivea showing a single type of bristles wich have a truncate tip. $\mathrm{H}$ : SEM micrograph of mericarp surface of $M$. luederitziana showing pockets surrounding the bristles base (Schlieben $8806, \mathrm{~W}$ ). 
non-conduplicated cotyledons and plumose awn.

In the analytic classification proposed by KNUTH (1912) (table 1) there are some natural groups; although we do not consider any taxonomic status for sect. Biflora, two species (M. brevirostrata, M. angustifolia) included in that section by Knuth form a natural group together with $M$. senegalensis in our analysis (subclade IV, fig. 14). Otherwise, Knuth's sections were not supported in the cladogram: Umbellatae, Ovata, Genistiformis, and Rotundatae.

Sarcocaulon is monophyletic. The three synapomorphies supporting its clade are also shared by the species not included in this analysis: succulent stems (character 2), stems covered by wax (character 3 ), and spines formed from leaf petioles (character 4).

\section{Character differentiation and evolution}

Most characters analysed in this study were already discussed by VENTER (1979). We have revisited all of them and searched for additional taxonomic information.

The annual life span seems to have arisen only once in Monsonia. The three annual species (M. angustifolia, M. senegalensis, $M$. brevirostrata) are usually colonizers. Two of them are distributed in a wide range of distribution and altitude, whereas $M$. brevirostrata occurs on mountainous bare ground (VENTER
1979). Although most annuals are derived in Geraniaceae (incl. Monsonia), there are several instances in Pelargonium (BAKKER \& al. 1998) and Geranium (YEO 1973) where perennials derived from annuals.

Leaf characters appear to have followed two different evolutionary patterns. Pinnate leaves have appeared twice, once involving most species of sect. Olopetalum and, independently, in $M$. nivea (sect. Monsonia). In contrast, subulate stipules and hair tufts occured once within sect. Olopetalum.

According to YEO (1990) pseudoumbels are considered an advanced feature in Geraniaceae due to suppression of bracts and internodes. Our cladistic analysis suggests that pseudoumbels in Monsonia are primitive while cymose inflorescences are derived.

Nectary features were already described in the literature (NARAYANA \& ARORA, 1963; Al-Nowaini \& Khalifa, 1973; Kumar, 1976; LINK, 1990; VOGEL, 1998). It is commonly accepted that they are derived from hydathodes in Geraniaceae (LINK, 1990; VOGEL, 1998). LiNK (1990) published a schematic and comprehensive classification of Geraniaceae nectaries, with three types: cryptothetic-staminal, phanerothetic-discoid, and cryptothetic-hypanthial. In Monsonia we have re-interpreted Link's classification considering three types: axillar, staminal with a protuberance, and staminal with a tube. In general, Link's
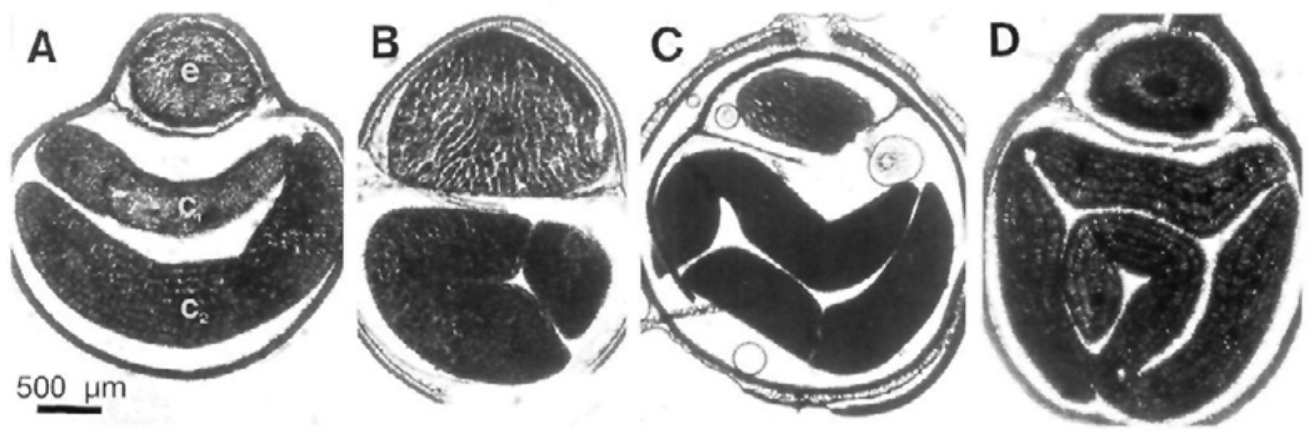

Fig. 13.-A: Light micrograph of mericarp section of Pelargonium peltatum, showing the embryonic axis (e) and the two unfolded, accumbent cotyledons ( $\mathrm{cl}$ and $\mathrm{c} 2$ ) (Cavanilles s.n., MA 252520). B: Light micrograph of mericarp section of $M$. umbellata, showing the embryonic axis and the two slightly folded cotyledons $(L . W$. Carisso \& F. Sousa 243, COI). C: Light micrograph of mericarp section of $M$. luederitziana, showing the embryonic axis and the two slightly folded cotyledons (Schlieben $8806, \mathrm{~W}$ ). D: Light micrograph of mericarp section of $M$. emarginata showing the embryonic axis and the two clearly folded cotyledons (Penther $2174 . \mathrm{W}$ ). 
cryptothetic-staminal are axillar and Link's phanerothetic-discoid are staminal with a protuberance. However, part of Link's cryptothetic-hypanthial nectaries are actually axillar, while the rest are staminal with a tube. A second character is found in a sepal structure related to nectar protection from desiccation: an enlargement at the sepal base, which encloses the nectary in pouches and is related to part of axillary nectaries. This structure was interpreted by Link as part of cryptothetic-hypanthial nectaries. Staminal nectaries with a protuberance have occurred twice, once involving some of species of sect. Olopetalum (subclades IV and V plus $M$. burkeana and $M$. praemorsa) and, independently, in part of sect. Monsonia (subclade VI). In contrast, staminal nectaries with a tube occurred only once within sect. Olopetalum. (subclade III). Additionally, sepals with pouches have appeared once within Monsonia, defining subclade VII.

The androecium in Monsonia consists of 15 anthers, except for $M$. brevirostrata which has a reduction to 5 fertile stamens plus 10 sterile filaments. Fertile stamen reduction has been observed in other genera of Geraniaceae such as in Pelargonium (VAN DER WALT, 1990), Geranium pusillum and G. biuncinatum (AEDO \& al. 1998, and unpublished data). Reduction in anther length $(<1 \mathrm{~mm})$ has occurred once within sect. Olopetalum (subclade IV) and twice in sect. Monsonia (M. deserticola, $M$. nivea plus $M$. heliotropioides; and $M$. umbellata), being likely associated with a shift to autogamy that has brought also a reduction in the number of pollen grains (as few as 8 in each anther of $M$. heliotropioides) and petal size ( $1.5 \mathrm{~mm}$ in $M$. nivea).

Supratectal processes define a clade of two species ( $M$. nivea and $M$. heliotropioides) within sect. Monsonia. Similar processes are present in many species of Geranium and Erodium, whereas Sarcocaulon and Pelargonium lack this character.

Four of the seven fruit characters considered in the cladistic analysis define the two sections of Monsonia. Mericarp detaching. consistency of columella, and mericarp wall thickness support the monophyly of sect.
Olopetalum, while plumose awn characterises sect. Monsonia. The two types of mericarp detaching were first found by PICARD (1837) and revisited by YEO (1990) in Geraniaceae, which also serve in our analysis to define the two sections. Mericarps separate upwards in sect. Monsonia, while in sect. Olopetalum they separate downwards (see also ZOHARY, 1972 , figures 332,345 and 350). Robustness of columella and mericarp are very variable characters in Geraniaceae (unpublished data) and may be related to dormancy (AEDo \& al. 1998). Plumose awn has been considered in the past a significant character to outline infrageneric groups in Monsonia and Erodium (BOISSIER, 1867).

The awn aids both seed dispersal and establishment in the soil (COBELLI, 1892; YEO 1990), as occurs in sect. Olopetalum. Additionally, mericarp devices contribute to mericarp burying in the following aspects: (1) the hygroscopic awn rotates and plants the mericarp; (2) the ridges on the top of mericarp are directed upwards and serve to enable penetration or retention of the mericarp underground; (3) the mericarp bristles are directed upwards, helping retain te mericarp underground; (4) the fusiform mericarp has a sharp callus on its bottom, to enable penetration of the soill. In contrast, plumose awns of sect. Monsonia do not aid to bury the mericarp because they are not sufficiently robust to penetrate in the soil nor do they aid rotation through humidity changes.

A shift from wind dispersal to adhesive dispersal by animals is suggested by phylogenetic reconstructions of Geraniaceae. Phylogenetic analysis of rbcL (PRICE \& PALMER 1993) and trnL-F (unpublished data) sequences suggests that the primarily wind-dispersed Pelargonium is sister group to the rest of Geraniaceae. Two main wind-dispersed mechanisms can be envisaged in Geraniaceae. One is present in most Pelargonium mericarps having a tuft of hairs from the basal to medial zone of the tails (similar to a pappus). The other is found in Monsonia, Sarcocaulon and Erodium and consists of a plumose awn. Mericarp structure associated with zoochory mode (SøRENSON, 1986, STEB- 


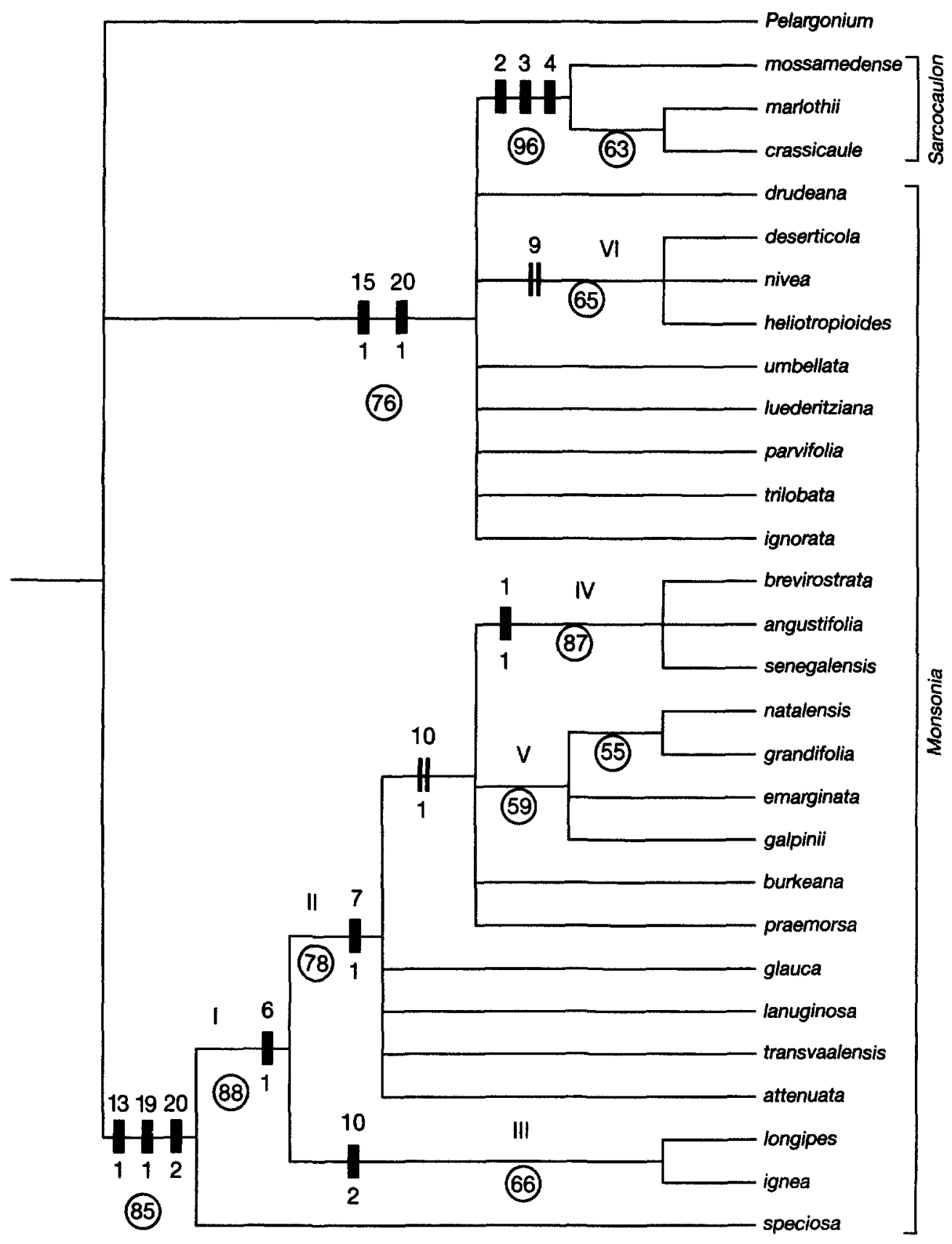

Fig. 14.-Strict consensus tree of 9 most parsimonious trees of Monsonia obtained from the analysis of 20 morphological and anatomical characters. Circled numbers indicate bootstrap values from 100 replicates. Solid bars are unambiguous synapomorphies, parallel lines are parallelisms; roman numbers designate clades referred to in the text. 
BINS, 1974) seems to be an advanced adaptation that occur independently in Geraniaceae, including sect. Olopetalum. Besides, animal dispersed mericarps are usually larger in Geraniaceae than those of the wind dispersed ones (LEISHMAN \& WESTOBY, 1994; GAJEWSKI 1959, 1963), and this is the case of sect. Olopetalum.

There is a pattern for cotyledon evolution in which a flat cotyledon has increasingly been folded to conduplicate cotyledons in sect. Olopetalum (YEO 1990). Cotyledon conduplication is also found in Erodium and Geranium, which might have occurred independently. Molecular phylogenetic studies, already in progress, may shed further light on this and depict a far more robust picture of morphological evolution in Monsonia and Geraniaceae as a whole.

\section{ACKNOWLEDGEMENTS}

The authors thank $M$. Jerez for aiding with microscopy preparations and photographs. F. Albers, G. Nieto Feliner, and an anonymous reviewer are thanked for helpful criticisms of the manuscript. We are indebted to the curators of the cited herbaria for kind assistance during our visits and for specimen loans. This work was partly financed by the Spanish DGICYT through the research projects PB96-0849 and REN2000-0818 GLO.

\section{REFERENCES}

Aedo, C., J.J. Aldasoro \& C. Navarro (1998). Taxonomic revision of Geranium L., sections Divaricata Rouy and Batrachioidea W. D. J. Koch (Geraniaceae). Ann. Missouri Bot. Gard. 85: 594-630.

Al-NowalH, A.S. \& KHalifa, S.F. (1973). Studies on some taxa of Geraniales. II. Floral morphology of certain Linaceae, Rutaceae and Geraniaceae with a reference to consistency of some characters. J. Indian Bot. Soc. 52: 198-206.

ALBERS, F. (1990). Comparative karyological studies in Geraniaceae on family, genus and section level. Proceedings of the International Geraniaceae Symposium. University of Stellenbosch.

ALBERS, F. (1996). The taxonomic status of Sarcocaulon (Geraniaceae). S. African J. Bot. 62(6): 345-347.

Bakker, F.T., D. HellbrügGe, A. Culham, \& M. GibBy. (1998). Phylogenetic relationships within Pelargonium sect. Peristera (Geraniaceae) inferred from nrDNA and cpDNA sequence comparations. Pl. Syst. Evol. 211: 273-287.
BOESEWINKEL F.D. (1997). Seed structure and phylogenetic relationships of the Geraniales. Bot. Jahrb. Syst. 119(2): 277-291.

BOESEWINKEL F.D \& W. BEEN (1979). Development of ovule and testa of Geranium pratense $L$. and some other representatives of the Geraniaceae. Acta Bot. Neerland. 28(4-5): 335-348.

BoIsSIER, E. (1867). Flora Orientalis, 1. Thalamiflorae. Basilieae et Genevae.

BORTENSCHLAGER, S. (1967). Vorläufige Mitteilungen zur Pollenmorphologie in der Familien der Geraniaceen und ihre systematische Bedeutung. Grana Palynol. 7(2-3): 400-468.

CANDOLle A.P. (1824). Prodromus systematis naturalis regni vegetabilis. Paris, Strasbourg \& London.

Cobelli, T. (1892). I Movimenti del fiore e del fruto dell'Erodium gruinum. Nuovo Giom. Bot. Ital. 24: 59-64

DOWNIE, S.R. \& J.D. PALMER (1992). Use of chloroplast DNA rpl2 intron in dicotyledons: molecular and phylogenetic implications. Evolution 45: 1245-1259.

DREYER, L.L., O.A. LEISTNER, P. BURGOYNE \& G.F. SMITH (1997). Sarcocaulon: genus or section of Monsonia (Geraniaceae)? S. African J. Bot. 63(4): 240.

FelsensteIN, J. (1985). Confidence limits on phylogenies: an approach using the bootstrap. Evolution 39: 783-791.

GAGEWSKI, W. (1959). Evolution in the genus Geum. Evolution 13: 378-388.

GAGEWSKI, W. (1963). The heredity of seed dispersing mechanisms in Geum. In: Genetics Today, Proceedings of the XI Congress of Genetics.ed. S. J. Geerts, pp. 423-430. Pergamon Press. New York.

HAIFA, O \& E. JouMENA (1991). Reports on chromosomic numbers. Int. Organ. Pl. Biosyst. Newslett. 17: 9.

Hegelmaier, F. (1899). Ueber convolutive cotyledons. Ber. Deutsch. Bot. Ges. 17: 121-139.

HuTCHINSON, J. (1969). Evolution and phylogeny of flowering plants. Academic Press, London.

KERS, L.E. (1968). Contributions to a revision of Monsonia (Geraniaceae). Bot. Notiser 121: 44-50.

KNUTH, R. (1912). Geraniaceae. In: A. Engler (ed.), Das Planzenreich, vol. 53. Berlin.

KUMAR, A. (1976). Studies in Geraniales. VII. The embriology of Erodium stephanianum Willd. Acta Bot. Ind. 4: 105-110.

Leishman, M.R. \& M. Westoby (1994). Hypotheses on seed size: tests using semiarid flora of Western New South Wales, Australia. Amer. Naturalist 143(5): 890906.

LINK. D.A. (1990). The nectaries of Geraniaceae. Proceedings of the International Geraniaceae Symposium. University of Stellenbosch.

Maddison, W.P. \& D.R. MadDison (1992). MacClade: Analysis of Phylogeny and Character Evolution. Version 3.0. Sunderland. Massachusetts: Sinauer Associates.

MOFFETT, R.O. (1979). The genus Sarcocaulon. Bothalia 12(4): 581-613.

MOFFET, R.O. (1997). The taxonomic status of Sarcocaulon:S. African J. Bot. 63(4): 239-240. 
NaRAYANA, H.S. \& P.K. ARORA (1963). The embryology of Monsonia senegalensis Guill. \& Perr. Amer. Midl. Naturalist 70(2): 310-318.

PICARD, C. (1837). Étude sur les Géraniées. Mém. Soc. Agric. Boulogne-sur-Mer 1: 95-138.

Price, R.A., P.J. CALle, S.R. DownIE, J.M. Logsdon \& J.D. PALMER (1990). Chloroplast DNA variation in the Geraniaceae: a preliminary report. In. Voster $\mathbf{P}$, ed. Proceeding of the International Geraniaceae Symposium. Stellenbosch.

Price, R.A. \& J.D. Palmer (1993). Phylogenetic relationships of the Geraniaceae from rbcL sequence comparisons. Ann. Missouri Bot. Gard. 80: 661-671.

SørEnson, A.E. (1986). Seed dispersal by adhesion. Annual Rev. Ecol. Syst. 17: 443-463.

STAFFoRd, P.J. \& M. GibBy (1992). Pollen morphology of the genus Pelargonium (Geraniaceae). Rev. Palaeobot. Palynol. 71: 79-109.

SteBbiNs, G.L. (1974). Flowering Plants: Evolution Above Species Level. Cambridge, Massachussets. Harvard University Press.

STRUCK, M. (1997). Floral divergence and convergence in the genus Pelargonium (Geraniaceae) in Southem Africa: ecological and evolutionary considerations. Pl. Syst. Evol. 208: 71-97.

SwEET, R. (1826). Hortus Brittanicus, vol. 4, 1" Edition, James Ridgeway, London.

SwOFFORD, D.L. (1993). PAUP: Phylogenetic Analysis Using Parsimony, version 3.1.1. Computer program distributed by the Illinois Natural History Survey, Champaign, Illinois.

ToliviA, D. \& J. Tolivia (1987). Fasga: a new polychromatic method for simultaneous and differential staining of plant tissues. J. Microscopy 148: 113-117.

VAN DER WALT, J.J.A. (1990). Taxonomic revision of Pelargonium: contributions of the Stellensbosch research team. In. Voster P, ed. Proceeding of the International Geraniaceae Symposium. Stellenbosch.

VENTER, H.J.T. (1979). A monograph of Monsonia L. (Geraniaceae). Meded. Landbouwhoogeschool Wageningen, Nederland 79(9): 1-128.

VENTER, H.J.T. (1983). Phytogeography and interspecies relationships in Monsonia L. (Geraniaceae). Bothalia 14(3\& 4): 865-869.

VENTER, H.J.T. (1990). An account of Monsonia L. (Geraniaceae). In. Voster P, ed. Proceeding of the International Geraniaceae Symposium. Stellenbosch.

VERHOEVEN, R.L. \& H.J.T. VeNTER (1986). Pollen morphology of Monsonia. S. African J. Bot. 52: 361-368.

VOGEL, S. (1998). Remarkable nectaries: structure, ecology, organophyletic perspectives IV. Miscellaneous cases. Flora 193: 225-248.

WARBURG E.F. (1938). Taxonomy and relationship in the Geraniales in the light of their cytology. New Phytol. 37: $130-159$.

YEO, P.F. (1973). The biology and systematics of Geranium, sections Anemonifolia Knuth and Ruberta Dum. Bot. J. Linn. Soc. 67: 285-346.

YEO P.F. (1984). Fruit-discharge type in Geranium (Geraniaceae): its use in classification and its evolutionary implications. Bot. J. Linn. Soc. 89: 1-36.
Yeo P.F. (1990). The classification of Geraniaceae. In: P. Voster (ed.), Proceeding of the International Geraniaceae Symposium. Stellenbosch.

ZoHARY, M. (1972). Flora Palestina, vol. 2, figures. The Israel Academy of Sciences and Humenities. Jerusalem.

\section{APPENDIX 1}

List of selected specimens used for the morphological and anatomical studies.

M. angustifolia A. Richard: Penther 2218 (W); Dinter 458 (COI); Lebrun 7919 (P).

M. attenuata Harvey: Gerrard 1431 (W); Schlechter 6827 (LE); Codd 8271 (K); Davidse 6725 (MO).

M. brevirostrata Knuth: Krook 2220 (W); Schlechter 6573 (LE); Van Wick 3925 (MO).

M. burkeana Harvey: Dinter 6611 (P); Heany 23 (COI); Schlechter 3581 (LE); Miller 2002 (K); Westfall 1587 (MO).

M. deserticola Knuth: Dinter 6611 (P); Kers s.n. (MO); Giess \& al. 5312 (MO); Giess \& al. 5461 (MO)

M. drudeana Schinz: Giess 14605 (K); Schenk 33 (P); Giess \& al. 5304 (MO).

M. emarginata (L. f.) L'Hér.: Penther 2174 (W); Ecklon 440 (LE); Van Wick \& Vorster 2265 (MO).

M. galpinii Knuth: Hilner 165 (P).

M. glauca Knuth: Dinter 5655 (P); Bruce 61 (MO); Pearson 7897 (K); Bayliss 6377 (MO); Smith 3258 (MO).

M. grandifolia Knuth: Rudatis 1342 (W); Medley Wood 6724 (LE); Hilliard 5468 (MO); Hilliard 8890 (MO); Haygatte 834 (MO); Edwards 106 (MO).

M. heliotropioides (Cav.) Boiss.: Rechinger 27633 (W); Schimper 306 (LE); Duthie s.n. (LE); Guinet \& Sauvage 232 (MPU).

M. ignea Schinz: Puccioni \& Stefanini 959 (P); Keller 50 (K); Ellis 184 (K).

M. ignorata Merxmüller \& Schreiber: Lavranos \& Pehlemann 19639 (MO); Lavranos \& Bleck 23760 (MO); Puff 780804 (W); Dinter 6019 (K); Giess 13423 (MO)

M. lanuginosa Knuth: Slechter 1308 (COI, LE, W); Nelson $536(\mathrm{~K})$.

M. longipes Knuth: De Wilde 6013 (MO); Ndegwa 745 (MO); Cufodontis 555 (W); Ndegwa 496 (MO); Amshof 669l (MO).

M. luederitziana Focke \& Schinz: Schlieben 8806 (W); Pearson 9755 (K); Leistner 2265 (K); Isaac 215 (MO). 
M. natalensis Knuth: Kuntze s.n. (P; K); Mc Clean $336(\mathrm{~K})$.

M. nivea (Decaisne) Webb: Kralik 26 (MA628481); Rechinger 27272 (W); Radcliffe 3739 (K).

M. parvifolia Schinz: Schlechter s.n. (W,LE); Schlechter s.n. (LE); Leach 13084 (K); Burger 3925 (MO)

M. praemorsa Knuth: Gerrard $388(\mathrm{~W})$; Gueinzius 452 (G).

M. senegalensis Guillemin \& Perrottet: Cardoso de Matos 6269 (MA-498297); Sauvage 75 (MPU); Kotschy 95 (W); Gillett 20125 (MO).

M. speciosa L.: Marloth s.n. (LE, W, P); Penther $2147(\mathrm{~W})$.
M. transvaalensis Knuth: Wilms $96(\mathrm{~K})$; Werdermann \& Oberdieck 2155 (P); Munday 2430 (MO).

M. trilobata Kers: de Winter 3548 (K); Theron 1960 (B).

M. umbellata Harvey: Carisso \& Sousa 243 (COI); Seydel 2947 (COI); Giess 3417 (W); Acocks 24551 (MO).

Pelargonium peltatum (L.) L'Her.: Cavanilles s.n. (MA-252520).

Sarcocaulon crassicaule Rehm.: Puff 780811 (W).

S. marlothii Engl.: Seydel 1126 (COI).

S. mossamedense (Welw. ex Oliv.) Hiern.: Exell \& Mendonça 2175 (COI).

Editado por Gonzalo Nieto Feliner Aceptado para publicación: 21-VI-2001 